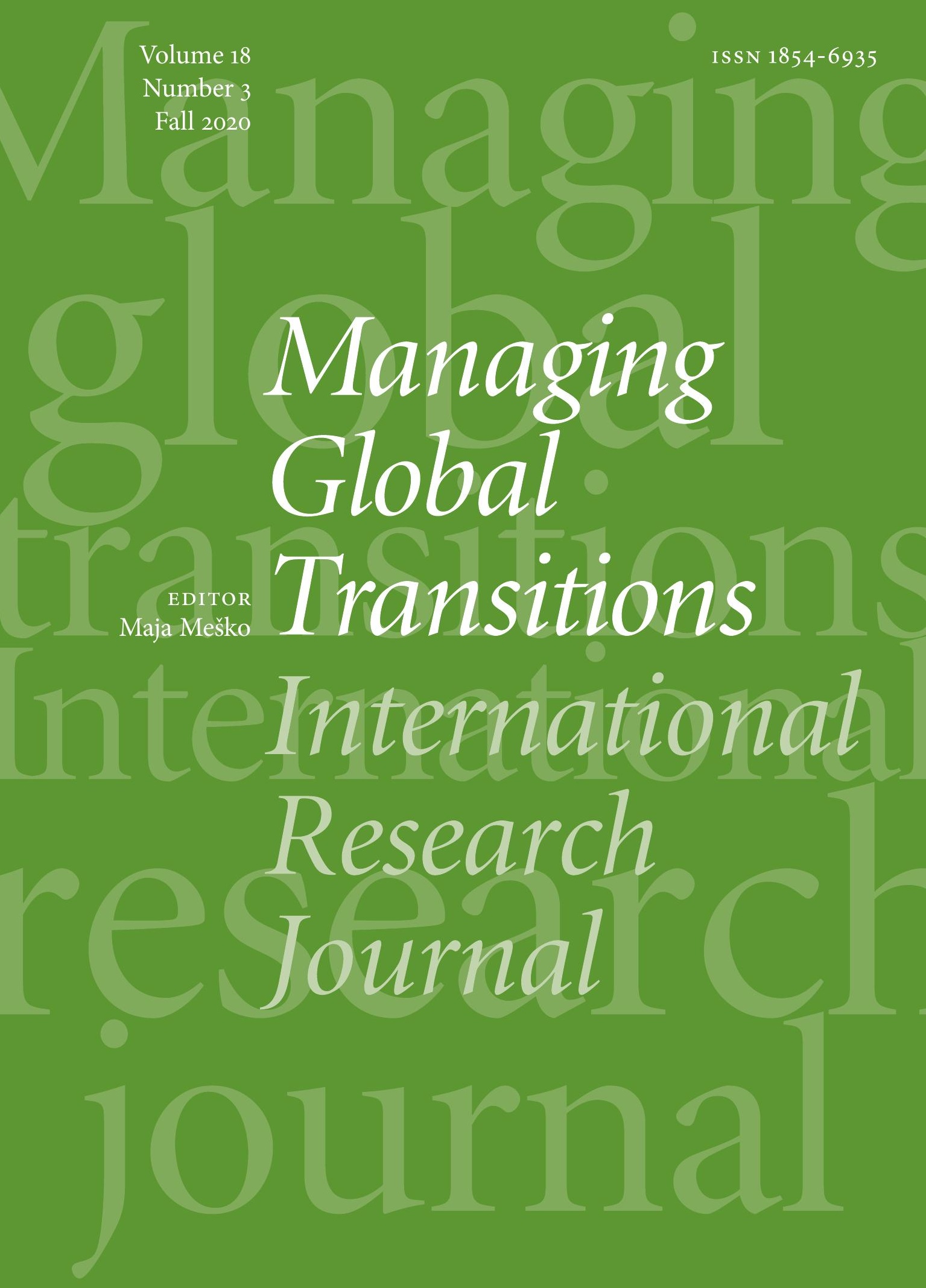




\section{Managing Global Transitions International Research Journal}

ISSN $1854-6935 \cdot$ www.mgt.fm-kp.si

EDITOR

Maja Meško, University of Primorska, Slovenia,maja.mesko@fm-kp.si

ASSOCIATE EDITORS

Andrej Bertoncelj, University of Primorska, Slovenia, andrej.bertoncelj@fm-kp.si

Gandolfo Dominici, University of Palermo, Italy,gandolfo.dominici@libero.it

Alexander Laszlo, Buenos Aires Institute of Technology, Argentina, alaszlo@itba.edu.ar

MANAGING AND PRODUCTION EDITOR

Alen Ježovnik, University of Primorska Press, Slovenia,alen.jezovnik@upr.si

EDITORIAL BOARD

Jani Bekő, Univerza v Mariboru, Slovenia, jani.beko@uni-mb.si

Heri Bezić, University of Rijeka, Croatia, bezic@efri.hr

Guido Bortoluzzi, University of Trieste, Italy, guido.bortoluzzi@deams.units.it

David L. Deeds, University of St. Thomas, usA,david.deeds@gmail.com

Evan Douglas, Griffith Universitiy, Australia, e.douglas@griffith.edu.au

Dean Fantazzini, Moscow School of Economics, Russia, fantazzini@mse-msu.ru

Henryk Gurgul, A GH University of Science and Technology, Poland, henryk.gurgul@gmail.com

András Inotai, Hungarian Academy of Sciences, Hungary, inotai.andras@krtk.mta.hu

Felicetta Iovino, University of Sannio, Italy, fiovino@unisannio.it

Hun Joon Park, Yonsei University, South Korea,hjpark@yonsei.ac.kr

Renata Karkowska, University of Warsaw, Poland,rkarkowska@wz.uw.edu.pl

Tanja Kosi Antolič, Institute of Macroeconomic Analysis and Development, Slovenia, tanja.kosi-antolic@gov.si
Leonard H. Lynn, Case Western Reserve University, UsA, leonard.lynn@case.edu Monty Lynn, Abilene Christian University, USA, monty.lynn@coba.acu.edu

Massimiliano Marzo, University of Bologna, Italy,massimiliano.marzo@unibo.it

Judita Peterlin, University of Ljubljana, Slovenia, judita.peterlin@ef.uni-lj.si

Mirjana Pejić Bach, University of Zagreb, Croatia,mpejic@efzg.hr

Sanja Peković, University of Crna Gora, Montenegro,psanja@ac.me

Sandra Penger, University of Ljubljana, Slovenia,sandra.penger@ef.uni-lj.si

Zdenko Prohaska, University of Rijeka, Croatia, zdenko.prohaska@efri.hr

José Solana Ibánez, Technical University of Cartagena, Spain, jose.solana@cud.upct.es

Marinko Škare, University of Pula, Croatia, mskare@unipu.hr

Nada Trunk Širca, International School of Social and Business Studies, Slovenia, trunk.nada@gmail.com

Šárka Velčovská, Technical University of Ostrava, Czech Republic, sarka.velcovska@vsb.cz

Manfred Weiss, Johann Wolfgang Goethe University, Germany, m.weiss@jur.uni-frankfurt.de

INDEXING AND ABSTRACTING

Managing Global Transitions is indexed/ listed in the International Bibliography of the Social Sciences, EconLit, I z Z Online, DoAJ, Erih Plus, EconPapers, Cabell's, EBsCO, and ProQuest.

SUPPORTED BY

Slovenian Research Agency.

Revija Managing Global Transitions je namenjena mednarodni znanstveni javnosti; izhaja $v$ angleščini s povzetki $v$ slovenščini. Izid revije je finančno podprla Javna agencija za raziskovalno dejavnost Republike Slovenije iz sredstev državnega proračuna iz naslova razpisa za sofinanciranje izdajanja domačih znanstvenih periodičnih publikacij. 


\section{Managing Global Transitions International Research Journal}

VOLUME $18 \cdot$ NUMBER 3 FALL 2O2O - ISSN 1854-6935

177 Effect of Technology Adoption on New Product Innovation

T. Joseph Musandiwa and Collins C. Ngwakwe

195 Relationship between Impulsivity, Value Orientations and Impulsive Buying

Katarina Sokić, Darija Korkut, and Aljoša Šestanović

211 Analysis of Collaboration between Enterprises and Public Research Organisations on Co-Financed Research-and-Development Projects

Tina Žitko and Borut Likar

237 Sustainable Growth-Environment Nexus in the Context of Four Developing Asian Economies: A Panel Analysis Mowshumi Sharmin and Mohammad Tareque

257 Abstracts in Slovene 
AIMS AND SCOPE

Managing Global Transitions (MGT) is a quarterly, scholarly journal that covers diverse aspects of transitions and welcomes research on change and innovation in increasingly digitalized and networked economic environments, from a societal, organizational, and technological perspective. MGT fosters the exchange of ideas, experience and knowledge among developed and developing countries with different cultural, organizational and technological traditions. MGT invites conceptual, theorydevelopment, empirical and review papers and case-based studies advancing the field of transitions in societies, organizations and technologies.

\section{TOPICS COVERED}

\section{Transitions in Societies}

- Geo-political transitions, transition experiments, pathways and mechanisms

- Social, demographic, cross-cultural, ethical, geo-political and security aspects of transitions

- Social change, prosperity, wellbeing, happiness

- Policy making, government regulation, social responsibility

- Knowledge-based society and world futures

- New and emerging metrics for measuring, assessing and evaluating societal transitions

\section{Transitions in Organizations}

- Organizational analysis and design, modeling, developments and changes in organizational learning and behavior

- International strategy and strategic alliances, networked businesses and operations

- Entrepreneurship and leadership, decision making

- Knowledge sourcing and innovation management, personal development, education and training, HRM

- Business systems and business models

- Connective intelligence and collective intelligence in organizational behavior
Transitions in Technologies

- Managing technological/organizational change and innovation

- Technology networks, technology transfer benefits and risks, technology acquisition and diffusion

- Smart technologies and development discontinuities, renewable sources and sustainability

- Digitalization, гот, гст, cybernetics, forecasting

- Technological traditions, strategic surprise and response systems

- Studies that promote understanding of the dynamics of socio-technical systems change

- Science and technology policy that fosters transformative advancement

- Modeling technological change in vucA (volatile, uncertain, complex, ambiguous) environments

SUBMISSIONS

The manuscripts should be submitted as e-mail attachment to the editorial office at mgt@fm-kp.si. Detailed guide for authors and publishing ethics statement are available at www.mgt.fm-kp.si.

\section{EDITORIAL OFFICE}

University of Primorska

Faculty of Management

Cankarjeva 5, 6104 Koper, Slovenia

mgt@fm-kp.si · www.mgt.fm-kp.si

PUBLISHED BY

University of Primorska Press

Titov trg 4, 6ooo Koper, Slovenia

zalozba@upr.si·www.hippocampus.si

Abstracts translated into Slovene

by Martina Paradiž and

Karin Podlipnik Bukovnik

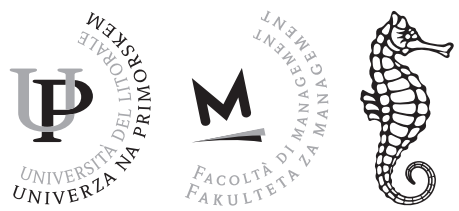




\section{Effect of Technology Adoption on New Product Innovation}

T. Joseph Musandiwa

University of Limpopo, South Africa

joseph.musandiwa@ul.ac.za

Collins C. Ngwakwe

University of Limpopo, South Africa

collins.ngwakwe@ul.ac.za

This paper examines the effect of licensing of foreign technology on new product innovation and market access. Data were collected from the archives of the World Bank's Global Enterprises Survey for fifty countries. The data were analysed using the Structural Equation Model (SEM) with the aid of STATA software. The SEM result show that licensing of external technology is positively and significantly related to new product innovation and access to market. However, the moderating independent variable (website usage) did not show a significant relationship with new product innovation and market access. The paper offers practical implication for new product innovation, which is that local enterprises can save the internal cost and time of research and development for new products by adopting the option of licensing foreign technology. This also has the advantage of assisting local enterprises to offer a new product to the market. Further research is recommended to add more countries to increase the number of observations.

Key Words: technology adoption, product innovation, foreign technology, technology licensing

JEL Classification: 032, O3, O31, 033, L6, M11

(c) BY-SA $\mathrm{https://doi.org/10.26493/1854-6935.18.177-194}$

\section{Introduction}

Enterprise product innovation involves much time and cost of internal research and development (R\&D) (Evangelista et al. 1998). Yet innovation is a vital competitive strategy to remain resilient in a dynamic global business environment (Salunke, Weerawardena, and McColl-Kennedy 2019). Given the cost and time of engaging in internal R\&D (Schuhmacher et al. 2018), some enterprises lag behind the fast changing technology with attendant loss of market niche. Therefore a veritable alternative to internal $R \& D$ is the adoption of licensing of external technology. Researchers 
indicate that it could offer the advantage of keeping up with new technology and enhancing access of new product to the market (Kotabe, Sahay, and Aulakh 1996).

There is an ever increasing need for local enterprises to consider options for being resilient and competitive amidst burgeoning globalisation with the attendant technological-innovation led competition (Siddharthan and Narayanan 2018; Ghosh and Roy 2018). Expert discussions in the literature opine that foreign technology adoption helps in product innovation and market entry (FAO, 2019). Licensing foreign technology assists local enterprises in the reduction of the intensity of local enterprises R\&D (Ghosh and Roy 2018). Technology plays a major role in contemporary product and service patronage by the market (Kotabe, Sahay, and Aulakh 1996). Hence avoidance of technology is tantamount to innovation avoidance, which can facilitate enterprise demise (Jiang et al. 2014). Product innovation is costly given the technology requirements. Therefore, the survival of local enterprises in a dynamically competitive world of business is to look for alternative technology to keep pace with global product trends (Rahman, Yaacob, and Radzi 2016). One of such alternative is licensing of foreign technology (Atuahene-Gima and Patterson 1993). Therefore, the objective of this paper is to examine the relationship between licensing of foreign technology and new product innovation. Hence, the research question is whether licensing of foreign technology is related to new product innovation. Extant research about the role of technology licensing on product innovation has concentrated on a country and regional level studies. This research makes contribution to existing research by engaging on a global study that uses data from fifty (50) different countries of the world.

The remaining portion of this paper is organised as follows. After this introduction, the paper presents a theoretical framework on innovation. This is followed by a review of the literature. Soon after the literature, the paper presents the hypotheses development section. This is followed by the method and result section. Thereafter, the paper ends with conclusion and recommendations.

\section{Theoretical Framework}

DISRUPTIVE INNOVATION THEORY

The disruptive innovation theory has enthralled the business management sphere. It is considered to be one such idea that is most persua- 
sive in the globalised business world (King and Baatartogtokh 2015). In his book The Innovator's Dilemma published in 1997, Christensen (2003) elucidated on the failure of renowned and exceptionally well managed organisations indicating that even the best of the managers are continuously at risk of ignoring competitors who are capable of introducing disruptive technologies. Disruptive technologies are considered to be those that add varied value and benefits to the general ones that are considered to be inferior when compared to mainstream technologies that enhance performance to targeted customers. As a consequence disruptive technologies have other features, considered to be cheaper, simpler, smaller, etc.; and may be used by new entrants in the market place and may be utilised at the lower end or in a new and niche markets (Hang and Chen 2008). While the term disruptive innovation may be used synonymously with disruptive technologies, Christensen and Raynor (2013) preferred to use the former because the application of the theory is not only used for products that are highly technological but can also be used for business model innovation. The disruptive innovation concept can be categorised as sustaining or disruptive. Sustaining innovations are implemented to sustain the firm's growth in the market (Hagedoorn and Cloodt 2003). In order to achieve continuous growth, a company needs to improve service/product features to appeal to the external users. Further, sustaining innovations can help improve the product given in its initial performance dimension designed to achieve specific customer value, in an incremental manner. While disruptive innovations are those that may disrupt even large firms with various major resources such as Research and Development facilities, highly skilled human capital, and other formidable absorptive capabilities (Hagedoorn and Cloodt 2003). To note disruptive innovations usually starts with inferior performing products, however when improvements are implemented their performance becomes much more superior when compared with their current counterparts, and end up replacing them.

\section{ABSORPTIVE CAPACITY THEORY}

The absorptive capacity theory was initially expounded by Cohen and Levinthal (1990) in the business management and organizational science domain. They used the theory as a construct at the company level. They defined absorptive capacity as the 'ability to recognize the value of new information, assimilate it, and apply it to commercial ends' (Cohen and Levinthal 1990, 128). The new information may be gathered from the in- 
ternal units in the firm or may also be from the outside of the formal innovating units (research and development) such as the manufacturing, marketing etc. The absorption capacity is not all about a firm acquiring and assimilating information, but it is also about the ability to exploit it for the advantage of the firm. It is about the ability for a company to acquire known knowledge that can be assimilated with new knowledge thereby use new knowledge for the benefit of the entire organization. As such knowledge utilization becomes important factor in predicting the benefits that result in developing innovative products or services. Researches done indicate that firms that are focused in conducting research and development are able to use information from the external sources (Mowery and Nathan 1983). Denoting that absorptive capacity is essentially the results the firm's research benefits (Cohen and Levinthal 1990). With current increased competition, many firms are increasingly competing based on the results of the research sophistication along with their available vast and integrated networks (Roijakkers and Hagedoorn 2006). Many multinational for example, apply their dispersed vast knowledge gathered from their subsidiaries and operations scattered globally (Chesbrough 2003). They use this integrated accumulated knowledge from the entire worldwide innovation networks to achieve competitive advantage (Bartlett and Ghoshal 1989). As they interconnect and leverage on the knowledge gathered from their various operational subsidiaries, they are able to develop, implement new innovative products as efficient as possible while at the same time responding and meeting their local client needs (Subramaniam and Venkatraman 2001). It is also indicated that absorptive capacity may develop from the manufacturing processes. It is suggested that the original measure for absorptive capacity is 'Research and Development ( R\&D) intensity, which is articulated as company unit-funded R\&D cost calculated as percentage of firm's unit sales and transfers (Cohen and Levinthal 1990).

Absorptive Capacity is an important theory particularly in information systems (Is) and knowledge management research (Addorisio et al. 2014). Many organizations spend large amounts of monies to services, infrastructure, software, and capacitating their human resources to develop absorptive and other related capabilities to use with newly acquired knowledge. As a result they are able to achieve and maintain a continuous growth and competitive advantage (Armstrong and Sambamurthy 1999).

Subsequently, Zahra and George (2002) reviewed and reconceptualise the absorption capacity concept as a capability that is dynamic relative to 
the creation of knowledge and how it is utilized to enhance and enable the firm to gain and maintain competitive advantage. In their conceptualization, two different absorptive capacities were identified, namely; potential absorptive capacity as well as the realized absorptive capacity. They indicated that potential absorptive capacity enables the firm to be receptive to gather and integrate the acquired external knowledge. Whereas realized absorptive capacity enables the firm to have transformation as well as exploitation capabilities. Transformation capabilities are those that are enabling the firm to develop practises that facilitate the combination of current known knowledge, newly acquired and integrated or assimilated knowledge. While exploitation capability referred to that which the organisation possesses in the application of acquired knowledge in those products or services resulting in the financial benefit for the organization.

\section{Literature Review}

\section{PRODUCT INNOVATION}

The new product development strategy plays a critical and fundamental role in the long term survival and competitiveness of any company. To be successful in the ever changing, competitive and global market; firms need to be innovative and explore new ideas in order to design and create new products (Martin 2009). The performance of many firms becomes unsatisfactory if they continue to focus in exploiting redundant past ideas, such as production processing and cost-cutting (Martin 2009). It is suggested that product innovation enables a firms to use knew knowledge to create new innovative products to develop and achieve a sustainable competitive advantage in the market environment (Shan and Jolly 2013; Defélix, Mazzilli, and Gosselin 2015). There are different types of company innovations that are vital to the process of creating new, enhanced capabilities or increased product use (Drucker 1985). Product innovation is vital as it is at the core of new product strategy. The introduction of new product is not only important in securing future profit growth but also in the corporate share price performance (Issah and $\mathrm{Ng}$ menipuo 2015). To be successful in implementing a new product strategy, a business needs to be competent and be able to invest substantial amount of resources in its research and development function, product design, marketing research and related departments. The firm needs to adopt an innovative culture. 
There are various types of innovation that a company may adopt, including: new products innovation, new production methods, identified new distribution and supply channels, market development, and creative ways to structure the organisation (Schumpeter 1934). Product innovation is thus referred to as the way new products or services are introduced in order to satisfy the identified needs of the market or external user (Damanpour 2017). It is also defined as the process of conceiving and implementing new products, including some of those activities such as $\mathrm{R} \& \mathrm{D}$, technical design and related marketing of new product and services. New products may include those that are completely new, additional new lines, and those that have modified ( $\mathrm{Li}$ and Atuahene-Gima 2001). Product innovation can be regarded as important factor in the medium- to long-term survival of firms (Pérez-Luño, Gopalakrishnan, and Valle-Cabrera 2014). When the firm adopts a product innovation strategy it enable the company to retain and expand its offerings to the fierce competitive markets (Baker and Sinkula 2009). Without adopting the product innovation strategy a firm may find it difficult to achieve its long term success. A firm with a product innovation strategy is able have capacity to withstand markets with fast changing consumer requirements and having highly technological advancements (Phromket, Prajudtasri, and Phangkhot 2010).

\section{INNOVATION PROCESS}

Literature indicates that product innovation and process innovation are related and are supplementary. Process innovation is regarded as the implementation of a new improved production and/or delivery methods (OECD 2005). The improvement may among other changes include techniques, equipment and related software. It may also be implemented to decrease factors such as unit cost of production, quality enhancement and new delivery methods. The innovation process may be regarded as transformational process in the innovation developmental framework. It emphasises re-innovation/re-invention process that emphasises the improvement of current process through cost reduction and performance of the entire production cycle (OECD 2005).

\section{COMPANY PERFORMANCE}

Firm performance is regarded as a business construct consisting of various dimensions that can be used to determine companies' achievement and success (Naser, Karbhari, and Mokhtar 2004; Yeung, Lee, and Chan 
2003). In the current competitive markets, conducting performance evaluation is considered to be a vital element to ensure that the developed and implemented business strategies are effective. Performance evaluation can thus be regarded as the process that is used to quantify if the production systems are efficient and also effective (Singh 2008). Various scholars have identified a number of measurements that can be used for organizational performance, and the four main dimensions are; the innovative performance, production performance, market performance and financial performance (Hagedoorn and Cloodt 2003; Yilmaz, Alpkan, and Ergun 2005). Innovation performance is defined as the market rewards that the firm derives from newly introduced products or services in the market as measured in terms of contribution to firm's sales income or its profits (Bakar and Ahmad 2010). Prajogo and Ahmed (2006) indicate that innovation performance is function of both product and process innovation measured on innovation output, rapidity of innovation, degree of innovativeness and the 'speed' to market. Considering operational performance, it can be measured based on numerous performance dimensional aspects including internal operational performance that may be relative to firm's product quality, its efficiency and productivity (Naser, Karbhari, and Mokhtar 2004). Further, firm performance may also be measured based on financial perspective. In today's customer-driven market environment, marketing competence resulting in capturing high market share is vital to achieve better financial results (Li 2000). Continuous sales revenues growth and decreasing marginal unit costs contribute to a high increase in the firm's overall profitability and also to the increase of share price (Venkatraman and Prescott 1990; Wang and Wei 2005).

\section{PRODUCT INNOVATION AND FIRM PERFORMANCE}

The relationship of product innovation and how it impacts on firm performance remains controversial and unresolved. The research work aimed at establishing the link between two business concepts remains complex and diverse. Empirical results in this regard are mixed. It has been acknowledged that firms that process innovating competences may often not achieve positive financial results from product innovation (Teece 1986). Conversely, it has been found that over two-thirds of research conducted show a relationship between product innovation and firm performance, while the rest indicate that there is a negative relationship or none at all (Capon, Farley, and Hoenig 1990). 
The results of the research conducted to investigate the relationship between company's performances and how it relates to innovation and research have revealed that a company is inclined to develop new innovations based on the importance to achieve a higher competitive advantage in the market (McAdam and Keogh 2004). It was further concluded that innovations have an impact on the firms' profits (Favre et al. 2000). Firms that have strong innovative culture were found to be more profitable and achieving high growth rate when compared to those who are not (Diederen, van Meijl, and Wolters 2002).

Various scholars indicate that innovation through the introduction of new product enhances long-term financial performance (Cheng, Lai, and $\mathrm{Wu}$ 2010; Pauwels at al. 2004). That is, companies that have adopted the innovative culture are able to develop products preferred by users and have favourable brand image enabling to attain higher market share, charge premium prices contributing to increased profit margins (Hanaysha, Hilman and Hasmini Abdul-Ghani 2014). Innovation is critical to the firm to achieve dominance in the market place and achieving high profitability (Cheng, Lai, and $\mathrm{Wu}$ 2010). Generally, innovation has high impact on the company's performance because it helps the firm to achieve improved market position and demonstrate attainment of competitive edge and superior performance level (Walker 2004). Research conducted indicate that companies which are more innovative are also concerned more with management techniques (Baldwin and Johnson 1996), thus contributing to the objective of achieving sustainable higher performance levels (Hult, Hurley, and Knight 2004). Product innovation in particular enables a firm to sustain competitive advantage, combat competition and create barriers of entry. It also enables these firms to dominate and become market leader, establish new distribution channels, and target new customers. Innovation provides firms with creative methods of doing business better than their competitors (Ahuja 2000). It was also concluded that when the firms is innovative it can significantly impact on the company's productivity knowledge capital (Hollenstein and Arvantis 2002).

Various scholars concur that product and process innovations play a vital supplementary role in impacting on the performance of an organisation. The two dimensions are managed they the firm can improve their competitiveness relative to its competitors, achieve high profitability, and improved market share (Cheng, Lai, and Wu 2010). Product innovation influences the firm to gain competitive edge through technology inno- 
vation, and as a result improving the product or service performance. Conversely, process innovations influences production efficiencies particularly when the firm implements newly adopted effective methods of producing current products or services (Evangelista and Vezzani 2010).

Notably, process innovation has a higher impact on the production cost, however its influence to the firm's growth and market share may be minimum when compared to product innovation (Cheng, Lai, and Wu 2010). Various empirical studies conducted conclude that for example, quality process and innovation positively impact on the firm's performance. It is further concluded that when Total Quality Management (TQM) is integrated with innovation there is a positive impact on company's profitability and market share (Kumar and Sharma 2017; Leavengood, Anderson, and Daim 2014).

\section{Hypothesis Development}

\section{TECHNOLOGY LICENSING, PRODUCT INNOVATION AND MARKET ACCESS}

There is an increase in the adoption of external technology licensing in creating new products and services, which serves as an alternative to researching and developing internal products and services (AtuaheneGima and Patterson 1993; Markman et al. 2005). The adoption of external technology licensing as an alternative to new product research and development is thus a management behaviour approach in responding to both internal and external competitive stimuli (Atuahene-Gima 1992). This serves two purposes namely to keep up with emerging technology, which would ordinary be costly for emerging enterprises and to gain market access with a new product (Ulas 2007). It has thus been opined that technology licensing enhances market access of new products (Boden and Goldstein 2018). Accordingly, many extant researches have been trying to examine if new technology product innovation does affect product performance in the market (Atuahene-Gima and Patterson 1993). But these previous researches have either concentrated on a country study or on a regional study. For instance, very recently (Wu, Ma, and Liu 2019) examined whether technology capability enhances new product performance in the market in large Chinese cities. Our paper contributes a nuance to existing research by examining this concept at a global level using a global data that covers fifty different countries.

We therefore hypothesise as follows, hypothesis 1: 
но There is no significant relationship between technology licensing and new product innovation and market access.

$\mathrm{H} 1$ there is a significant relationship between technology licensing and new product innovation and market access

\section{WEBSITE AND PRODUCT DEVELOPMENT AND MARKET ACCESS}

In many companies across the world, enterprise website has constituted a veritable platform for increasing business undertakings (Kuivalainen 2009). In their research, Kuivalainen (2009) unravelled the effect of enterprise website on enterprise product development. They find that web site in a service company helps to improve customer experience and attendant patronage. Supportive research does confirm that enterprise communication strategy affects new product performance (Lee and O'Connor 2003). Current researches on persuasive power of website confirm that website facilitates positive consumer patronage and purchasing behaviour (Hamid et al. 2019; Tang, Yang, and Shao 2019).

We therefore hypothesise as follows, hypothesis 2:

но There is no significant relationship between enterprise website development and new product innovation and market access

$\mathrm{H} 1$ There is a significant relationship between enterprise website development and new product innovation and market access.

\section{Method and Results}

Data were collected from the World Bank archive of Global Enterprise Survey (World Bank 2019). Given that the previous literature had highlighted the important contribution of enterprise foreign technology licensing and enterprise website ownership on product innovation (Atuahene-Gima 1992; Kuivalainen 2009), the paper thus extracted these three variables from the aforementioned World Bank's data archive for the first fifty countries in the global enterprise survey data (after eliminating the countries with incomplete data within this first range of fifty countries). Data were analysed quantitatively using the Structural Equation Model (SEM). This was justified on the ground that data were stationery. Hence the two variables namely foreign technology licensing and enterprise website ownership were the independent variables, whilst the percentage of new products in the market served as the depended variable, to show how foreign technology licensing and web site ownership by enterprises can after the dependent variable. 
TABLE 1 Result of Structural Equation Model (SEM) for Foreign Technology Licensing, Enterprise Website Ownership and Percentage of New Products in the Market

\begin{tabular}{lrrrrrr}
\hline Item & $(1)$ & $(2)$ & $(3)$ & $(4)$ & $(5)$ & $(6)$ \\
\hline Licensed foreign tech. & 0.571 & 0.232 & 2.460 & 0.014 & 0.116 & 1.026 \\
Website & -0.034 & 0.081 & -0.420 & 0.673 & -0.192 & 0.124 \\
Constant & 61.850 & 5.174 & 11.950 & 0.000 & 51.708 & 71.992 \\
Mean (licensed tech.) & 13.648 & 0.961 & 14.200 & 0.000 & 11.765 & 15.531 \\
Mean (website) & 47.226 & 2.764 & 17.090 & 0.000 & 41.809 & 52.643 \\
Var (new product, & 124.477 & 24.895 & & & 84.111 & 184.218 \\
new in mark) & & & & & & \\
Var (licensed tech.) & 46.169 & 9.233 & & & 31.197 & 68.327 \\
Var (website) & 381.981 & 76.396 & & & 258.108 & 565.305 \\
Cov (licensed tech, & 1.634 & 18.782 & 0.090 & 0.931 & -35.178 & 38.447 \\
website) & & & & & & \\
\hline
\end{tabular}

Notes Column headings are as follows: (1) coefficient, (2) orm standard error, (3) $Z$, (4) $p$ > IzI, (5-6) 95\% confidence interval.

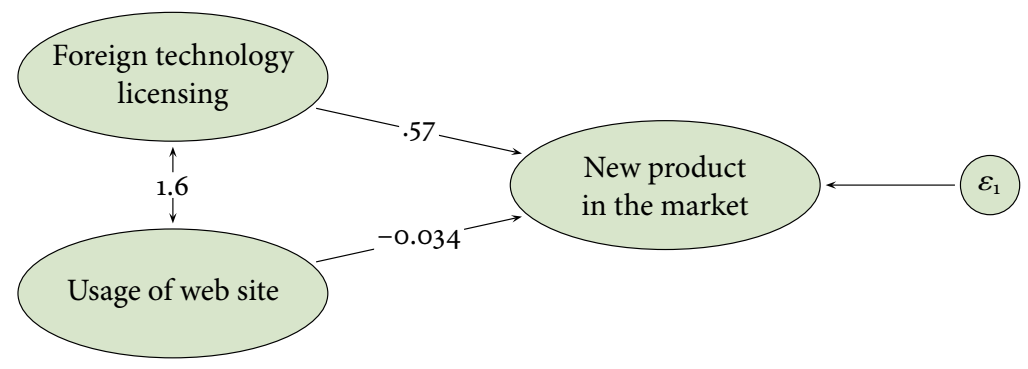

FIGURE 1 Structural Equation Model Graph

\section{Discussion and Conclusion}

Results depicted in table 1 one and in figure 1 show that the number of companies amongst the fifty sample, which are adopting the licensing of foreign technology has a low mean of 13.6 compared to the mean of companies using web with a higher mean of 47.2. This means that more global companies are using web site technology to promote innovation of products, whilst little number of companies is using licensed foreign technology. Furthermore, the number of companies using web site technology tends to vary more than the number of companies using licensed foreign technology at 382 and 46 for licensed foreign technology and web site usage respectively. Regarding whether there is a covariance between 
the independent variables (licensed foreign technology and web site usage), the analysis in table 1 show a $p$-value of 0.93 , which is higher than the alpha level of $0.05(5 \%)$. This means there is no covariance between the two independent variables. Importantly, the SEM in table 1 vshow that the number of companies with licensed foreign technology is positively and significantly related to innovation of a new product in the market at a $p$-value of 0.014 , which is lower than the alpha of 0.05 . Therefore the null hypothesis 1 is rejected in favour of the alternative hypothesis 1 , which suggests that foreign technology licensing has a positive and significant effect on new product innovation. However, the usage of web site shows no significant relationship with innovation of a new product in the market at a $p$-value of 0.67 which is higher than the alpha level of 0.05 . Accordingly, the null hypothesis 2 is accepted, which suggests there is no significant relationship between web site usage and new product innovation.

This result is consistent with prior literature conducted at country or regional studies, which show that licensed foreign technology, can enhance new product innovation into the market. But this research has proven this assertion at a global level by examining companies from fifty different countries. The findings of this research is consistent with previous research conducted at a country level, wherein technology adoptive capacity was found to be significantly related to new product development (Chen and Chang 2019; Lim and Kim 2018).

The practical implication is that companies can achieve the same objective of new product innovation by saving on internal $R \& D$ cost to adopt foreign technology licensing (United Nations and African Union 2014). This also has an added advantage of showcasing the latest technology that is in vogue in international market, which ordinarily an average enterprise may not be able to afford the cost (Atuahene-Gima 1992).

The findings of this research hold particular implication for developing countries - mostly for African countries that have the lowest rate of productivity and competitiveness compared to other continents in the world. Since technology drives innovation, production of new products and the attendant competiveness, African countries and other developing countries with low capacity to initiate new technology for production may adopt technology licensing to drive innovation and new product development in Africa. There is the likelihood that if this strategy of technology adoption is sustained, developing nations such as Africa may experience an upward positive trend from its lowest productivity and com- 
petitive position. This proposition thus calls for further research in two fronts namely to increase the number of countries used from fifty in this research to greater number and for other research to create a pool of developing countries and conduct and empirical examination of how technology licensing may improve innovation, new product development and competitiveness in developing countries.

\section{References}

Addorisio, M., S. Gao, W. Yeoh, and S. F. Wong. 2014. 'Critical Analysis of the Use of Absorptive Capacity Theory in Is Research.' In Proceedings of the 5th International Conference on Information Systems, 1-15. Auckland: Association for Information Systems.

Ahuja, G. 2000. 'Collaboration Networks, Structural Holes and Innovation: A Longitudinal Study'. Administrative Science Quarterly 45:42555 .

Armstrong, C. P., and V. Sambamurthy. 1999. 'Information Technology Assimilation in Firms: The Influence of Senior Leadership and IT Infrastructures.' Information Systems Research 10 (4): 304-27.

Atuahene-Gima, K. 1992. 'Inward Technology Licensing as an Alternative to Internal R\&D in New Product Development: A Conceptual Framework.' Journal of Product Innovation Management 9 (2): 156-67.

Atuahene-Gima, K., and P. Patterson. 1993. 'Managerial Perceptions of Technology Licensing as an Alternative to Internal $\mathrm{R} \& \mathrm{D}$ in New Product Development: An Empirical Investigation.' R\&D Management 23 (4): $327-36$.

Bakar, L. J. A., and H. Ahmad. 2010. 'Assessing the Relationship between Firm Resources and Product Innovation Performance: A ResourceBased View. Business Process Management Journal 16 (3): 420-35.

Baker, W. E., and J. M. Sinkula. 2002. 'Market Orientation, Learning Orientation and Product Innovation: Delving into the Organization's Black Box.' Journal of Market-Focused Management 5 (1): 5-23.

Baldwin, J., and J. Johnson. 1996. 'Business Strategies in More and Less Innovative Firms in Canada.' Research Policy 25 (5): 785-804.

Bartlett, C., and S. Ghoshal. 1989. Managing Cross Borders. Boston, MA: Harvard Business School Press.

Boden, M., and J. Goldstein. 2018. 'Licensing Medical Devices to Manufacturers/Partnering With Large Companies.' In Medical Innovation: Concept to Commercialization, edited by K. E. Behrns, B. Gingles, and M. G. Sarr, 51-63. Cambridge, M A: Academic Press.

Capon, N., J. U. Farley, and S. Hoenig. 1990. 'Determinants of Financial Performance: A Meta-Analysis.' Management Science 36 (10): 1143-59. 
Chen, M. N., and Y. C. Chang. 2019. 'Absorptive Capacity, Appropriability Depth and New Product Development in Taiwanese Service Firms.' Asian Journal of Technology Innovation 27 (1): 108-33.

Cheng, C., M. Lai, and W. Wu. 2010. 'Exploring the Impact of Innovation Strategy on R\&D Employees' Job Satisfaction: A Mathematical Model and Empirical Research.' Technovation 30 (9): 459-70.

Chesbrough, H. W. 2003. Open Innovation: The New Imperative for Creating and Profiting From Technology. Boston, MA: Harvard Business School Press.

Christensen, C. M. 2003. The Innovator's Dilemma: When New Technologies Cause Great Firms to Fail. New York: HarperCollins.

Christensen, M. C., and M. E. Raynor. 2013. The Innovator's Solution: Creating and Sustaining Successful Growth. Boston, M A: Harvard Business School Press.

Cohen, W. M., and D. A. Levinthal. 1990. 'Absorptive Capacity: A New Perspective on Learning and Innovation.' Administrative Science Quarterly 35 (1): $128-52$.

Damanpour, F. 2017. 'Organizational Innovation.' Oxford Research Encyclopedia of Business and Management. https://doi.org/10.1093/acrefore/ 9780190224851.013.19

Defélix, C., I. Mazzilli, and A. Gosselin. 2015. 'Articuler les politiques de GRH et les stratégies d'innovation: des modèles à l'épreuve des faits.' Revue de Gestion des Ressources Humaines 2 (1): 60-72.

Diederen, P., H. van Meijl, and A. Wolters. 2002. 'Innovation and farm Performance.' In Innovation and Firm Performance, edited by A. Kleinknecht and D. Mohnen, 73-85. London: Palgrave.

Drucker, P. F. 1985. 'The Discipline of Innovation.' Harvard Business Review 63 (3): $67-72$.

Evangelista, R., and A. Vezzani. 2010. 'The Economic Impact of Technological and Organizational Innovations: A Firm-Level Analysis.' Research Policy 39 (10): 1253-63.

Evangelista, R., T. Sandven, G. Sirilli, and K. Smith. 1998. 'Measuring Innovation in European Industry'. International Journal of the Economics of Business 5 (3): 311-33.

Favre, F., S. Negassi, and E. Pfister. 200o. 'The effect of Spillovers and Government Subsidies on R\&D, International R\&D Cooperation and Profit.' In Innovation and Firm Performance, edited by A. Kleinknecht and P. Mohnen, 201-24. London: Palgrave.

Ghosh, M., and R. P. Roy. 2018. 'F DI, Technology Imports and R \& D in Indian Manufacturing: Revisited.' In Globalisation of Technology, edited by N. S. Siddharthan and K. Narayanan, 127-49. Singapore: Springer.

Hagedoorn, J., and M. Cloodt. 2003. 'Measuring Innovative Performance: 
Is There an Advantage in Using Multiple Indicators?' Reasearch Policy 32 (8): 1365-79.

Hamid, N. A., C. H. Cheun, N. H. Abdullah, M. F. Ahmad, and Y. Ngadiman. 2019. 'Does Persuasive E-commerce Website Influence Users' Acceptance and Online Buying Behaviour? The Findings of the Largest E-commerce Website in Malaysia.' In ICT for a Better Life and a Better World, edited by Y. Baghdadi and A. Harfouche, 263-79. Lecture Notes in Information Systems and Organisation 30. Cham: Springer.

Hanaysha, J., H. Hilman, and N. Hasmini Abdul-Ghani. 2014. 'Direct and Indirect Effects of Product Innovation and Product Quality on Brand Image: Empirical Evidence from Automotive Industry.' International Journal of Scientific and Research Publications 4 (1): 2250-3153.

Hang, C. C., and J. Chen. 2008. 'Disruptive Innovation: An Appropriate Innovation Approach for Developing Countries.' E TM Internal Report, no. 1/o8:1-34.

Hagedoorn, J., and M. Cloodt. 2003. 'Measuring Innovative Performance: Is There an Advantage in Using Multiple Indicators?' Research Policy 32:1365-79.

Hollenstein, H., and S. Arvantis. 2002. 'The Impact of Spill Overs and Knowledge Heterogeneity Confirm Performance: Evidence from Swiss Manufacturing.' In Innovation and Firm Performance: Econometric Explorations of Survey Data, edited by A. Kleinknecht and P. Mohnen, 225-52. Basingstoke: Palgrave Macmillian.

Hult, G. T. M., R. F. Hurley, and G. A. Knight. 2004. 'Innovativeness: Its Antecedents and Impact on Business Performance.' Industrial Marketing Management 33 (3): 429-38.

Issah, O., and I. M. Ngmenipuo. 2015. 'An Empirical Study of the Relationship between Profitability Ratios and Market Share Prices of Publicly Traded Banking Financial Institutions in Ghana.' International Journal of Economics, Commerce and Management United Kingdom 3 (12): 2742.

Jiang, J., J. McPherson, A. Wittman, S. Limarta, T. H. Wang, J. Pessey, and P. Tippayasawate. 2014. 'How Businesses Fail in Managing Technology: A Review of the literature.' In Proceedings of PICMET'14 Conference, 58597. New York: IEEE.

Kotabe, M., A. Sahay, and P. S. Aulakh. 1996. 'Emerging Role of Technology Licensing in the Development of Global Product Strategy' Journal of Marketing 6o (1): 73-88.

King, A. A., and B. Baatartogtokh. 2015. 'How Useful Is the Theory of Disruptive Innovation?' MIT Sloan Management Review, 15 September. https://sloanreview.mit.edu/article/how-useful-is-the-theory-of -disruptive-innovation 
Kuivalainen, O. 2009. 'Complementary Role of Website in Business Model Development.' In Emergent Strategies for E-Business Processes, Services and Implications: Advancing Corporate Frameworks, edited by I. Lee, 136-54. Hershey, PA: I I Global.

Kumar, V., and R. R. K. Sharma. 2017. 'Relating Management ProblemSolving Styles of Leaders to TQM Focus: An Empirical Study' The TQM Journal 29 (2): 218-39.

Leavengood, S., T. R. Anderson, and T. U. Daim. 2014. 'Exploring Linkage of Quality Management to Innovation.' Total Quality Management and Business Excellence 25 (9-10): 1126-40.

Lee, Y., and G. Colarelli O'Connor. 2003. 'The Impact of Communication Strategy on Launching New Products.' Journal of Product Innovation Management 20 (1): 4-21.

Li, L. 200o. 'An Analysis of Sources of Competitiveness and Performance of Chinese Manufacturers.' International Journal of Operations and Production Management 20 (3-4): 299-315.

Lim, J., and B. K. Kim. 2018. 'The Effects of Entrepreneurship Orientation and Absorptive Capacity on Corporate Performance: Focusing on Mediating Effects of Product Innovation Performance.' Journal of Korea Technology Innovation Society 21 (4): 1536-76.

Markman, G. D., P. T. Gianiodis, P. H. Phan, and D. B. Balkin. 2005. 'Innovation Speed: Transferring University Technology to Market.' Research Policy 34 (7): 1058-75.

Martin, R. 2009. The Design of Business: Why Design Thinking is the Next Competitive Advantage. Boston, MA: Harvard Business Press.

McAdam, R., and K. Keogh. 2004. 'Transitioning towards Creativity and Innovation Measurement in SM Es.' Creativity and Innovation Management 13 (2): 126-41.

Mowery, D. C., and R. Nathan. 1989. Technology and the Pursuit of Economic Growth. New York: Cambridge University Press.

Naser, K., Y. Karbhari, and M. Z. Mokhtar. 2004. 'Impact of Iso 9000 Registration on Company Performance: Evidence from Malaysia.' Managerial Auditing Journal 19 (4): 509-16.

OECD. 2005. Oslo Manual: Proposed Guidelines for Collecting and Interpreting Technological Innovation Data. Paris: OECD.

Pauwels, K., J. Silva-Risso, S. Srinivasan, and D. M. Hanssens. N.d. 'New Products, Sales Promotions, and Firm Value: The Case of the Automobile Industry.' Journal of Marketing 68 (4): 142-56.

Pérez-Luño, A., S. Gopalakrishnan, and R. Valle-Cabrera. 2014. 'Innovation and Performance: The Role of Environmental Dynamism on the Success of Innovation Choices.' IE EE Transactions on Engineering Management 61 (3): 499-510. 
Phromket, C., P. Prajudtasri, and D. Phangkhot. 2010. 'The Influences of Product Innovation Development on Performance: An Empirical Study of Electronics and Electrical Equipment Industry in Thailand.' Journal of Academy of Business and Economics 10 (1): 78-88.

Prajogo, D. I., and P. K. Ahmed. 2006. 'Relationships between Innovation Stimulus, Innovation Capacity and Innovation Performance.' $R \& D$ Management 36 (5): 499-515.

Rahman, N. A., Z. Yaacob, and R. M. Radzi. 2016. 'An Overview of Technological Innovation on sme Survival: A Conceptual Paper.' Procedia: Social and Behavioral Sciences 224:508-15.

Roijakkers N., and J. Hagedoorn. 2006. 'Inter-Firm R\&D Partnering in Pharmaceutical Biotechnology since 1975: Trends, Patterns, and Networks.' Research Policy 35 (1): 431-46.

Salunke, S., J. Weerawardena, and J. R. McColl-Kennedy. 2019. 'The Central Role of Knowledge Integration Capability in Service InnovationBased Competitive Strategy'. Industrial Marketing Management 76:14456.

Schuhmacher, A., O. Gassmann, N. McCracken, and M. Hinder. 2018. 'Open Innovation and External Sources of Innovation: An Opportunity to Fuel the R\&D Pipeline and Enhance Decision Making?' Journal of Translational Medicine 16 (1): 119. https://doi.org/10.1186/s12967-0181499-2

Schumpeter, J. A. 1934. The Theory of Economic Development: An Inquiry into Profits, Capital, Credit, Interest, and the Business Cycle. New Brunswick, NJ: Transaction Publishers.

Shan, J., and D. R. Jolly. 2013. 'Technological Innovation Capabilities, Product Strategy, and Firm Performance: The Electronics Industry in China.' Canadian Journal of Administrative Sciences 30 (3): 159-72.

Siddharthan, N. S, and K. Narayanan. 2018. Globalisation of Technology. Singapore: Springer.

Singh, P. 2008. 'Empirical Assessment of iso 9000 Related Management Practices and Performance Relationships.' International Journal of Production Economics 113 (1): 40-59.

Subramaniam, M., and N. Venkatraman. 2001. 'Determinants of Transnational New Product Development Capability: Testing the Influence of Transferring and Deploying Tacit Overseas Knowledge.' Strategic Management Journal 22 (4): 359-78.

Tang, Y., Y. T. Yang, and Y. F. Shao. 2019. 'Acceptance of Online Medical Websites: An Empirical Study in China.' International Journal of Environmental Research and Public Health 16 (6): 943. https://doi.org/10 .3390/ijerph16060943.

Teece, D. J. 1986. 'Profiting from Technological Innovation: Implications 
for Integration, Collaboration, Licensing and Public Policy.' Research Policy 15 (6): 285-305.

Ulas, D. 2007. 'Eu Market Access: The Way of Licensed Warehousing System for Turkish Food Producers and Exporters.' Poster paper prepared for presentation at the 105th EA A E Seminar International Market and International Trade of Quality Food Products, Bologna, 8-10 March.

United Nations and African Union. 2014. 'Innovation and Technology Transfer for Enhanced Productivity and Competitiveness in Africa.' https://www.uneca.org/sites/default/files/uploadeddocuments/CoM/ com2014/com2014innovation_and_technlogy_transfer_for_enhanced _productivity_and_connectiveness_in_africa-english.pdf

Venkatraman, N., and J. E. Prescott. 1990. 'Environment Strategy Coalignment: An Empirical Test of its Performance Implications.' Strategic Management 11 (1): 1-23.

Walker, R. M. 2004. 'Innovation and Organizational Performance: Evidence and a Research Agenda.' Research Working Paper 2, Advanced Institute of Management, University of Hong Kong.

Wang, E. T. G., and H. L. Wei. 2005. 'The Importance of Market Orientation, Learning Orientation, and Quality Orientation Capabilities in TQM: An Example from Taiwanese Software Industry’ Total Quality Management 16 (10): 1161-77.

World Bank. 2019. 'Enterprise Survey.' https://www.enterprisesurveys.org/ en/data/exploretopics/innovation-and-technology

Wu, J., Z. Ma, and Z. Liu. 2019. 'The Moderated Mediating Effect of International Diversification, Technological Capability, and Market Orientation on Emerging Market Firms' New Product Performance.' Journal of Business Research 99:524-533.

Yeung, A. L., T. S. Lee, and L. Y. Chan. 2003. 'Senior Management Perspectives and Is 9000 Effectiveness: An Empirical Research.' International Journal of Production Research 41 (3): 545-69.

Yilmaz, C., L. Alpkan, and E. Ergun. 2005. 'Cultural Determinants of Customer and Learning Oriented Value Systems and Their Joint Effects on Firm Performance.' Journal of Business Research 58 (12): 1340-52.

Zahra, S., and G. George. 2002. 'Absorptive Capacity: A Review, Reconceptualization, and Extension.' Academy of Management Review 27 (2): 185-203. 


\title{
Relationship between Impulsivity, Value Orientations and Impulsive Buying
}

\author{
Katarina Sokić \\ Effectus, Croatia \\ ksokic@effectus.com.hr \\ Darija Korkut \\ Effectus, Croatia \\ dkorkut@effectus.com.hr \\ Aljoša Šestanović \\ Effectus, Croatia \\ asestan@effectus.com.hr
}

The aim of this study was to examine the role of impulsivity and value orientations in impulsive buying on a convenience sample from the City of Zagreb $(N=220,44 \%$ male $)$, ages ranged from 20 to 55 years $\left(M_{\text {age }}=26.07\right.$, SD = 7.14). A Barratt impulsivity scale, Buying Impulsivity Scale, and Value Orientation Scale was administered. The result showed that impulsive buying is associated with attention, motor and non-planning impulsivity. Also, the results have revealed a positive association between impulsive buying tendencies and hedonistic value orientation. Hierarchical regression analysis showed that motor and non-planning impulsivity, but not attention impulsivity, positively predict impulsive buying tendencies. Additionally, impulsivity and value orientations explained $35 \%$ of the variance in impulsive buying tendencies. The results suggest that impulsive buying behavior is primarily associated with a hedonistic value orientation.

Key Words: impulsivity, value orientations, impulsive buying JEL Classification: A13, D12, D87, D 91

(c) BY-SA https://doi.org/10.26493/1854-6935.18.195-210

\section{Introduction}

Although impulsive buying behaviours have already been investigated as early as Freud (1911), this early work was focused on motivation, mainly associating impulse buying with the hedonic id, which is driven by pleasure, selfishly and irrationally seeking instant gratification, without any regard for the consequences. However, prior to Rook (1987) the research in the area of impulse buying behavior focused primarily on external stimuli, i.e. product characteristics rather than buyer's personality traits. 


\section{FIGURE 1}

Impulse Buying Behavior Framework (adapted from Muruganantham and Bhakat 2013)

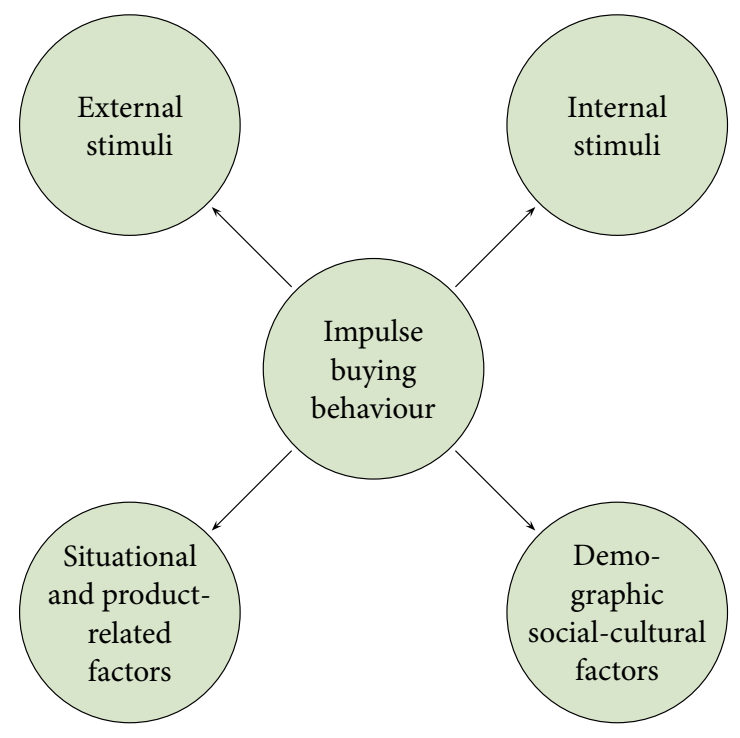

Compiling relevant literature on the topic into a detailed review, $\mathrm{Mu}-$ ruganantham and Bhakat (2013) offer an extensive insight into findings in the area of impulse buying, distinguishing four different sources of stimuli: (1) external, (2) internal, (3) situational and product related, and (4) demographics socio-cultural factors.

Majority of authors focus their research on external stimuli as marketers and corporations use it for their campaign and sales purposes, and although external and internal stimuli have repeatedly been proven to closely interact in their impact on impulsive buying behaviours, internal reasons for such behaviours have still been thoroughly underinvestigated, particularly in the Croatian context. As this study examines the influence of impulsivity and value orientation on impulsive buying tendencies, primary interest of the research is in the area of internal stimuli, linking personality traits to impulsiveness and hedonism.

Relevant literature studying buying behavior identifies Openness, Extraversion, and Neuroticism as personality traits positively associated with impulsive buying tendencies, while Conscientiousness and Agreeableness are identified as negatively associated with the impulsive buying behavior. However, previous studies have not clearly suggested whether impulsiveness was more closely related to Extraversion or to Neuroticism, which is attributed mostly to the complexity of the impulsiveness construct. In an attempt to resolve these concerns, Lange et al. (2017) used 
data from student and clinical samples in three studies with the subscales of the Barratt Impulsiveness Scale (B Is): IM (motor impulsiveness - involves acting without thinking), IA (Attentional Impulsiveness - refers to the inability to focus on the task at hand) and INP (non-planning impulsiveness - reflects a lack of future orientation), which helped them place different facets of impulsiveness in different places of a multidimensional personality framework. Their results suggest that student samples show positive correlations between IM and Extraversion and between IA and Neuroticism. In the clinical sample involving individuals with elevated levels of impulsiveness, the relationship between IM and Extraversion was found to be weakened whereas the relationship between IA and Neuroticism was substantially stronger when compared to the non-clinical sample.'

Among the first to study impulsive buying tendencies in Croatia were Bošnjak, Bandl, and Bratko (2007). Their made a methodological contribution proposing their own instrument - an 8-item preliminary scale to assess cognitive (e.g. lack of planning and deliberation) and affective aspects (e.g., feeling of pleasure, excitement, compulsion, lack of control, regret) of impulsive buying tendencies. They adapted the instrument originally developed by Verplanken and Herabadi (2001), and though citing certain limitations of the preliminary scale, the instrument they developed might be of wide application assisting all - from market researchers who want to identify consumer segments particularly susceptible to impulsive buying to screening impulsive buying tendencies in clinical applications. On the research side, Bošnjak, Bandl, and Bratko (2007) open room for descriptive comparisons of impulsive buying tendencies and behaviours in different cultures as well as a line of research in exploring 'cultural comparability of the generic base of such tendencies, i.e. by relating impulsive buying to more general personality traits in different cultures.'

Farid and Ali (2018) study the impact of personality on impulse buying behavior, emphasizing that the need for this kind of studies in developing countries might be greater than in developed ones due to rapid growth in the international and local retailing sector in developing countries. Hoping to discover unique behavior of Pakistani consumers compared to other developed countries, their results only confirmed the role of personality in encouraging impulse buying at retail outlets, with openness, conscientiousness, extraversion and neuroticism being the dimensions that showed positive correlation with impulse buying.

Similar to Bošnjak, Bandl, and Bratko (2007), Badgaiyan, Verma, and 
Dixit (2016) provided their indigenous scale for measuring impulsive buying tendency in an attempt to better grasp its impact on impulsive buying behavior in consumers in different cultures. Badgaiyan, Verma, and Dixit (2016) made an important contribution to studying impulsive buying tendency by initially developing a new impulsive tendency measurement two factor scale comprising of 8 items. The scale was validated in the second study by studying the relationship between impulsive buying tendency and self-control, impulsive buying behavior, and the Big Five personality traits of emotional stability, agreeableness, extraversion, conscientiousness, and openness to experience. Their results confirmed that personality constructs of extraversion and conscientiousness were significantly related to impulsive buying tendency. They also found positive relationship between impulsive buying tendency and impulsive buying behavior, and a negative relationship between impulsive buying tendency and self-control, which in turn validated the measurement qualities of their scale. Kacen and Lee (2002) wrote about these cultural differences when studying the impact of culture on consumer behavior in impulse purchasing. Their results point to essential underlying differences between consumers in Western individualist societies and those in Eastern collectivist cultures suggesting that the interaction of culture and consumers needs to be taken into account when attempting to better understand impulsive buying behavior.

Shehzadi et al. (2016) investigated relationship between personality traits and compulsive buying behavior with mediating role of impulsive buying. They found that individuals who score higher on agreeableness, neuroticism, and openness could be 'compulsive buyers with existing propensity of impulsivity'. Also, they confirmed some previous research in this area suggesting insignificant relationship between conscientiousness and with impulsive buying because these buyers plan their spending. However, neurotic personalities are emotionally instable so they buy excessively and on the spur of the moment to reduce stress.

Chen and Lee (2015) empirically examined hierarchical relationships of personality traits and impulsiveness in online buying. The results show that agreeableness, need for arousal, and need for material were predictive of online buying impulsiveness. On the other hand, value consciousness was negatively related to online buying impulsiveness as this study proposed and positively related to conscientiousness. Defining conscientiousness as an 'organized, orderly, and efficient carrying out of tasks,' authors showed that it could also be useful for predicting the tendency 
to carry out purchase tasks efficiently. Furthermore, variety seeking tendency was proved to be related but not antecedent variable of online buying impulsiveness.

Cai et al. (2015) studied narcissism in relation to impulsive buying. They hypothesized that narcissism, characterized by impulsivity and materialism, might serve as a potential antecedent to impulsive buying. In two separate studies, they found that adaptive narcissism was not correlated with impulsive buying, while maladaptive narcissism was significantly predictive of the impulsive buying tendency. Furthermore, the results indicate that global narcissism and its two components, adaptive and maladaptive narcissism, as well as the impulsive buying tendency were heritable. Connections between global narcissism and impulsive buying, and between maladaptive narcissism and impulsive buying were genetically based, helping thus identify the origins of that link between narcissism and impulsive buying.

Values play an important role in understanding consumer behavior. Values are the sources of both attitudes and behavior, and represent what people believe is important in their lives; they are the internal guidelines (guides) of human behavior (Schwartz 1994; Schwartz and Bilsky 1990). Values are the result of socialization, personal experiences and the environment, and they significantly affect the attitudes and behavior of the individual (Schwartz 1996; Rohan and Zanna 2001). One of the most commonly used value models is the Schwartz model (1992), which links values to Maslow's theory. The model emphasizes that values arise from the needs of the individual.

Authors studying values (e.g. Rokeach 1973; Schwartz 1992) agree that there is a number of universal values that all people have, but their composition varies with respect to their significance to the individual. Differences are conditioned by the personality and social environment in which the individual grows up and acts, which leads to different value systems. According to Franc, Šakić, and Ivičić (2002), values are grouped into three value orientations: conventional, self-realizing and hedonistic. These authors emphasize that conventional value orientation is a protective factor of socialization, while hedonist value orientation is a risk factor of different forms of maladaptive behaviours such as alcohol and drug abuse. Hedonistic orientation includes thrill-seeking, proneness to comfortable life, striving for a high standard of living and seeking fun and excitement. It is positively related to disinhibition, a construct similar to impulsivity, which encompasses negative affects and problems of impulse 
control (Ljubin Golub and Sokić 2016). In contrast, conventional orientation includes educational aspiration, helping others and honesty, and living in accordance with one's moral principles and is negatively related to disinhibition (Ljubin Golub and Sokić 2016).

Relationship between impulsivity and impulsive buying is clear at first sight. It is reasonable to assume that these two constructs have a positive association due to the impulsive tendencies that underlie them.

In this paper we focus on the B Is model of impulsivity (Patton, Stanford, and Barratt 1995), which includes three dimensions of impulsivity: attention, motor and non-planning. Attention impulsivity reflects the inability to focus on the task and includes attention and cognitive instability. Motor impulsivity is a combination of quick and reckless action and inconsistent lifestyle. Non-planning impulsivity reflects a lack of selfcontrol (planning and careful reflection) and lack of cognitive complexity (enjoyment of complex mental tasks). The study by Mao et al. (2018), which uses B IS-11 as a measure of impulsivity, has shown a positive association between impulsivity and neuroticism, and a negative association between impulsivity and self-control.

\section{Literature Review}

There has been a long history of impulsive buying behavior, initially associated with acts of childishness, immaturity, stupidity and lack of intelligence (Farid and Ali 2018). Impulsive buying, today widely recognized as a complex behaviour, is thoroughly researched not just as psychological multifaceted phenomena, but for its economic significance as well. Impulsive shopping is an intriguing area of consumer behavior and a key field of marketing considerations (Kesić and Kursan 2008). According to some researchers, impulsive buying behavior has become the most significant trend in today's world (Shakaib and Ali 2018). Thus, investigating and discovering the factors surrounding impulsive buying may lead to creating such profit oriented sales strategies that, in economically favourable environment, may induce and stimulate impulsive buying. Impulse buying may result due to external stimuli, controlled by marketers to lure customers into impulse buying (Shakaib and Ali 2018). For example, some research results show that the impulsive buying to some extent is affected by use of sales promotions at the point of sale and the dynamic display of merchandise in creating an adequate atmosphere and an attractive, smart and purchase stimulating store (Mihić and Kursan 2010). 
Impulsive buying, seemingly simply defined as unplanned purchase, or purchasing without planning in advance, is rather complex worldwide phenomena related with emotions, cognitive, and behavioural characteristics of individuals in general. Furthermore, certain analysis have shown that cultural context and cultural differences factors (individualist culture as compared to collectivism culture) moderate many aspects of consumer's impulsive buying behavior, including self-identity, normative influences, the suppression of emotion, and the postponement of instant gratification (Kacen and Lee 2002). Not surprisingly, because of its attributions related to availability of purchasing channels, disposable income, etc. the phenomenon of impulsive buying is thoroughly studied in developed, i.e. consumer oriented countries. The Muruganantham and Bhakat (2013) thoroughly reviewed and classified wide opus of studies that investigate impulsive buying behaviour. Only few studies that investigate the phenomena of impulsive buying is available for developing countries, e.g. Shakaib and Ali (2018).

With rapid globalization and technologically backed development of e-commerce, Internet buying channels, and availability of 'one-click' buying it can be argued that this phenomena is gaining momentum in other countries as well. With dramatic increases in personal disposable income, life style and credit availability have made impulse buying a widespread phenomena across the different retail formats (Muruganantham and Bhakat 2013). The need of studying impulsive buying is more in developing countries as compared to developed countries due to the recent development in the retailing sector in developing countries (Kacen and Lee 2002).

Hausman (2000) argues that impulse shopping is complicated, huge and multi-dimensional concept due to which very large number of products and services are sold yearly. Some researchers thus found that individual' are responsible for impulsive buying contrarily to previous believe that the 'product' contributes impulsive buying (Jalees 2009). From individual customer perspective, impulsive buying can be simply described as as a very spontaneous purchase or taking ownership of the product without any deeper thinking (Shakaib and Ali 2018). More compound definition of impulsive buying described it as a hedonically complex purchasing behavior in which the rapidity of the impulse purchase decision process precludes thoughtful, deliberate consideration of all information and choice alternatives (Kacen and Lee 2002). In that context, simple classification of individuals on impulsive and non-impulsive buyers may be 
tempting. Nevertheless, it was also found the level of impulsiveness in reference to purchasing, varied from time to time for both the impulsive buyers and non-impulsive buyers (Jalees 2009).

Contrary to some studies that individual personality consider as a main determinant of impulsive buying, Kesić and Kursan (2008) oppose two paradigms of modern marketing related to impulsive buying. According to situational paradigm, the consumer becomes a passive participant in the process of behavior, and that his purchasing decisions are mainly influenced by external factors. Hyperreal paradigm considers impulsivity as determined by individual personality. The authors conclude that impulsivity as a personal characteristic of the consumer potentially exists, but situational factors are important for the manifestation of impulsive buying because research has shown that they determine the intensity and frequency of impulsive consumer behavior.

This evidence is confirmed from Mihić and Kursan (2010) that investigated the correlation between situational factors and impulsive buying behavior in Croatia. They conclude that most situational factors to some extent induce shoppers to buy on impulse and thus proposed several practical suggestions to retailers and their sales staff. Iyer et al. (2020) conducted the meta-analysis that integrates findings from 231 samples and more than 75,000 consumers in order to determine relationship between impulse buying and its determinants, associated with several internal and external factors. They concluded that traits (e.g., sensation-seeking, impulse buying tendency), motives (e.g., utilitarian, hedonic), consumer resources (e.g., time, money), and marketing stimuli emerge as key triggers of impulse buying.

The relationship between impulsivity measured by the в Is, impulsive buying and values is intriguing, but not well explored and the current study aims to examine the relationship between different dimensions of impulsivity as indexed by the B Is-11, impulsive buying and value orientations. Previous research has shown that impulsivity is related to socially unacceptable behaviours, like aggression (Houston et al. 2003) and destructive communication (Tan, Jarnecke, and South 2017). Additionally, impulsivity traits correlate negatively with self-regulation (Hofmann et al. 2014). Impulsivity per se is a diagnostic criterion for a wide range of mental disorders including ADHD, borderline personality disorder, bulimia, antisocial personality disorder (American Psychiatric Association 2013), and is therefore expected to be unrelated to conventional and selfrealization values. 


\section{The Present Study and Hypotheses}

The aim of this study was to investigate relationships between impulsivity, values, and impulsive buying. We suggest that understanding of these relationships can help clarify the mechanisms underlying reckless and harmful consumer's decisions.

Consistent with Rook and Fisher's (1995) conceptualization of impulsive buying, and in line with previous research (e.g., Sokić, Horvat, and Krakan 2019; Bratko, Horvat, and Krakan 2013), we hypothesize that impulsive buying will be positively associated with attention, motor, and non-planning impulsivity (Hypothesis 1).

Consistent with previous findings (Ljubin Golub and Sokić 2016) and conceptualization of values (Franc, Šakić, and Ivičić 2002) we predict a positive association between impulsive buying and hedonistic value orientation, and negative association between impulsive buying and conventional values (Hypothesis 2).

\section{Methodology}

\section{PARTICIPANTS AND PROCEDURE}

In this research we used convenience sample ( $N=220,56 \%$ women). Participants' ages ranged from 20 to 55 years $\left(\mathrm{M}_{\text {age }}=26.07, \mathrm{SD}=7.14\right)$. Most of them were married (65\%) and employed (92\%). All participants were informed about the nature of the study and they participated on a voluntary basis.

\section{MEASURES}

Impulsivity was measured by the Baratt impulsivity scale (в I S-11; Patton, Stanford, and Barratt 1995). This questionnaire is a 4-point Likert-type scale and consists of 30 items which assess attention (e.g. I don't 'pay attention,' I 'squirm' at plays or lectures, I often have extraneous thoughts when thinking), motor (e.g. I change jobs, I act on the spur of the moment, I buy things on impulse), and non-planning (e.g. I say things without thinking, I am more interested in the present than the future) impulsivity.

Values were measured using Value Orientation Scale (vos; Franc, Šakić, and Ivičić 2002) which consists of 18 items grouped into three value orientations: conventional ( 5 items), self-realizing ( 6 items) and hedonistic ( 7 items). The vos is five-point Likert scale (from $1=$ not important at all to $5=$ very important). 
TAB LE 1 Descriptive Statistics and Internal Consistency Values

\begin{tabular}{llrrrrr}
\hline Item & & $(1)$ & $(2)$ & $(3)$ & $(4)$ & $(5)$ \\
\hline BIS-11 & Attentional impulsivity & 16.82 & 3.37 & 0.44 & 0.39 & 0.67 \\
& Motor impulsivity & 21.31 & 3.92 & 0.45 & 0.94 & 0.71 \\
& Non-planning impulsivity & 22.67 & 4.22 & -0.08 & -0.38 & 0.72 \\
\hline Values & Conventional & 25.16 & 3.05 & -0.55 & 0.19 & 0.78 \\
Orientations & Self-realization & 22.67 & 2.06 & -1.27 & 1.68 & 0.80 \\
& Hedonistic & 26.20 & 4.35 & -0.26 & 0.87 & 0.76 \\
& Impulsive buying & 25.87 & 6.65 & 0.39 & -0.13 & 0.89 \\
\hline
\end{tabular}

Notes Column headings are as follows: (1) median, (2) standard deviation, (3) skewness, (4) kurtosis, (5) Cronbach's $\alpha . N=220$.

Impulsive buying was measured by the Impulsive Buying Scale (I BS; Rook and Fisher 1995). This seven-point Likert scale consists of nine items (e.g. I buy things according to how I feel at the moment, I often buy things spontaneously, I carefully plan most of my purchases).

\section{Results}

\section{DESCRIPTIVE STATISTICS}

Results of descriptive statistics are presented in table 1. Alpha coefficient scores as indicator of internal reliabilities are adequate for all scales (in a range from 0.67 to 0.89 ).

Additionally, results of all scales showed adequate range. According to Gravetter and Walnau (2014), skewness and kurtosis scores were acceptable (i.e. in a range from -2 to +2 ).

\section{CORRELATION AND REGRESSION ANALYSES}

Pearson's correlation coefficients are displayed in table 2. Intercorrelations between impulsivity scales are low to moderate (from o.3o between attention and non-planning impulsivity to 48 between attention and motor impulsivity), which is in line with earlier findings (e.g., Gatner, Douglas, and Hart, 2016; Sokić and Ljubin Golub 2019).

Values orientations scale demonstrated low to moderate intercorrelations (from 0.20 between conventional and hedonistic values to 0.55 between conventional and self-realization values).

As predicted, impulsive buying is positively associated with attention, motor, and non-planning impulsivity. In line with hypotheses, impulsive 
TABLE 2 Pearson's Correlation Coefficients

\begin{tabular}{lcccccc}
\hline & 2 & 3 & 4 & 5 & 6 & 7 \\
\hline 1. Attention impulsivity & $0.48^{* *}$ & $0.30^{* *}-0.23^{* *}$ & $-0.13^{*}$ & $0.17^{* *}$ & $0.28^{* *}$ \\
2. Motor impulsivity & $-0.31^{* *}$ & $-0.13^{*}$ & -0.05 & $0.19^{* *}$ & $0.54^{* *}$ & \\
3. Non-planning impulsivity & $-0.15^{*}$ & $-0.18^{* *}-0.04$ & $0.30^{* *}$ & & \\
4. Conventional v.o. & $-0.55^{* *}$ & $0.20^{* *}$ & 0.02 & & & \\
5. Self-realization v.o. & $-0.27^{* *}$ & 0.07 & & & \\
6. Hedonistic v.o. & $-0.16^{* *}$ & & & & \\
7. Impulsive buying & & & & & & \\
\hline
\end{tabular}

NOTES ${ }^{*} p<0.05,{ }^{* *} p<0.01 . N=220$.

buying showed a positive association with hedonistic values, but not a negative association with conventional values.

Results of multiple regression analysis (table 3) showed that hedonistic values and motor and non-planning impulsivity positively predicted impulsive buying.

As we have seen, predictors explained $35 \%$ of the variance in impulsive buying. Value orientations entered in Step 2 explained 6\% of the variance in impulsive buying, thus partially confirming Hypothesis 2. Impulsivity components accounted for $29 \%$ of unique predictive variance beyond values. As expected, motor and non-planning impulsivity but nor attention impulsivity, were positive predictors of impulsive buying, partially confirming Hypothesis 1. However, the positive relationship between impulsive buying and hedonistic value orientation became non-significant after adding impulsivity dimensions. This result suggests that we can attribute positive relationship between impulsive buying and hedonistic values to the overlap of hedonistic values with impulsivity.

Conclusion and Practical Implications

The main goal of this study was to explore relations between impulsive buying, impulsivity and values. Results of correlation analysis partially confirmed our hypotheses. As predicted, at a bivariate level, impulsive buying was positively associated with all impulsivity dimensions. These results were expected and logical because Rook's construct of impulsive buying is based on behavioural, cognitive, and emotional features of impulsivity. Therefore, impulsive buying and impulsivity are partially overlapping constructs underlying similar psychological mechanisms. First, these are the lack of impulse control, impaired affect regulation and behavioural restraint. As expected, impulsive buying was positively related 
TA B LE 3 Multiple Hierarchical Regressions Predicting Impulsive Buying from the Impulsivity and Values

\begin{tabular}{|c|c|c|c|c|c|c|}
\hline Predictors & (1) & (2) & (3) & (4) & (5) & (6) \\
\hline Step 1 & & & $0.04^{* *}$ & $0.04^{* *}$ & $5.48^{\star *}$ & \\
\hline Gender & 0.21 & $3.22^{\star *}$ & & & & \\
\hline Age & -0.09 & -1.36 & & & & \\
\hline Step 2 & & & $0.08^{\star}$ & $0.06^{*}$ & $4.27^{\star *}$ & $0.04^{\star x}$ \\
\hline Gender & 0.24 & $3.58^{* *}$ & & & & \\
\hline Age & -0.05 & -0.74 & & & & \\
\hline Conventional v.o. & -0.07 & -0.98 & & & & \\
\hline Self-realization v.o. & 0.04 & 0.46 & & & & \\
\hline Hedonistic v.o. & 0.20 & $2.93^{* *}$ & & & & \\
\hline Step 3 & & & $0.37^{* *}$ & $0.35^{* *}$ & $17 \cdot 34^{* *}$ & $0.29^{\star x}$ \\
\hline Gender & 0.18 & $3.21^{\star *}$ & & & & \\
\hline Age & -0.18 & -0.32 & & & & \\
\hline Conventional v.o. & 0.03 & 0.45 & & & & \\
\hline Self-realization v.o. & 0.08 & 1.30 & & & & \\
\hline Hedonistic v.o. & 0.06 & 1.14 & & & & \\
\hline Attention impulsivity & 0.06 & 1.02 & & & & \\
\hline Motor impulsivity & 0.46 & $7.50^{* *}$ & & & & \\
\hline Non-planning impulsivity & 0.14 & $2.47^{\star}$ & & & & \\
\hline
\end{tabular}

NOTES Column headings are as follows: (1) standardized beta coefficients, (2) $t$, (3) coefficient of determination $\left(R^{2}\right)$, (4) adjusted $R^{2},(5) F,(6)$ change for impulsivity dimensions entered in a separate step after controlling for gender, age, and values. ${ }^{*} p<0.05$, ${ }^{* *} p<0.01 . N=220$. Criterion: impulsive buying.

to hedonistic values. This result is in line with the conceptualization of hedonistic value orientations (Franc, Šakić, and Ivičić 2002) as values characterized by thrill-seeking, aspiring towards comfortable life, striving for a high standard of living and seeking fun and excitement.

Also, our result corresponds to previous findings which show positive associations of all в Is-11 scales and hedonistic values but only in female sample (Ljubin Golub and Sokić 2016). In this study, we did not investigate gender differences between examined variables, which should be done in future research.

As expected, hedonistic values were found to be positively related to impulsive buying and explained $4 \%$ of the variance. Contrary to our 
hypotheses, conventional value was insignificant predictor of impulsive buying. Impulsivity dimensions explained an additional $29 \%$ of variance over the values, with values becoming insignificant. Our results suggest that impulsivity dimensions (especially motor and non-planning impulsivity), outperform values and are more relevant to impulsive buying than values. Although impulsive buying is partly explained by impulsivity dimensions and value orientations, a large amount of the variance in impulsive buying (i.e., 65\%) remains unexplained, suggesting that other factors are also important. Among such factors, the environmental/contextual factors are probably among most influential.

Thus, impulsive buying, despite numerous studies and empirical evidences, still remains complex psychological and economical phenomena. Although intriguing from psychological standpoint, it can be argued that discovering determinants and factors inducing individuals to impulsive buying still remains Holy Grail to marketers and profit seekers in retail industry all around the world. Current study shows that some aspects of impulsivity (e.g., motor, and non-planning dimensions of this construct) have a very important role in understanding impulsive buying tendencies. Also, hedonistic values significantly predict impulsive buying. Gender explained a significant amount of variance in impulsive buying, thus future research should explore the role of gender in relations between examined variables. Overall, this study can help us better understand impulsive buying, which has an important role in consumer behavior and is becoming a growing problem today.

This study has some limitations. The first limitation of this work is the use of self-report measures given the impact of shared method variance. The use of a convenience sample may not exhibit the full range of impulsivity. Therefore, future studies should use general population samples, and clinical and incarcerated samples. Future research also needs to include other impulsive buying measures, primarily different cognitive and affective aspects of impulsive buying, aimed at better understanding of the relationship between examined variables. Likewise, using behavioural tasks consideration should be given to measuring both, impulsivity, and impulsive buying. In addition, future research should be conducted with control of socio-demographic variables, such as monthly income, marital status, and educational level. As mentioned above, the results show that a large amount of the variance in impulsive buying remains unexplained. Thus, future research should explore the role of regret, depression, anxiety, stress, but also other emotions in the context of impulsive buying. 


\section{References}

American Psychiatric Association. 2013. Diagnostic and Statistical Manual of Mental Disorders. 5 th ed. Washington, DC: American Psychiatric Association.

Badgaiyan, A., A. Verma, and S. Dixit. 2016. 'Impulsive Buying Tendency: Measuring Important Relationships with a New Perspective and an Indigenous Scale.' IIм в Management Review 28 (4): 181-246.

Bošnjak, M., A. Bandl, and D. Bratko. 2007. 'Measuring Impulsive Buying Tendencies in Croatia: Towards a Parsimonious Measurement Scale.' In Marketing u društvu znanja i suvremenoj poslovnoj stvarnosti, edited by B. Grbac, 426-35. Rijeka: CROMAR.

Bratko, D., A. Butković, and M. Bošnjak. 2013. 'Twin Study of Impulsive Buying and Its Overlap with Personality. Journal of Individual Differences 34 (1): 8-14.

Cai, H., Y. Shi, X. Fang, and Y. L. L. Luo. 2015. 'Narcissism Predicts Impulsive Buying: Phenotypic and Genetic Evidence.' Frontiers in Psychology 6:881. https://www.doi.org/10.3389/fpsyg.2015.00881

Chen, T., and M. C. Lee. 2015. 'Personality Antecedents of Online Buying Impulsiveness.' Journal of Economics, Business and Management 3 (4): 425-29.

Farid, D. S., and M. Ali. 2018. 'Effects of Personality on Impulsive Buying Behavior: Evidence from a Developing Country'. Marketing and Branding Research 5 (1): 31-43.

Franc, R., V. Šakić, and I. Ivičić. 2002. 'Vrednote i vrijednosne orijentacije adolescenata: hijerarhija i povezanost sa stavovima i ponašanjima.' Društvena istraživanja 11 (2-3): 215-38.

Freud, S. 1911. 'Formulations on the Two Principles Mental Functioning.' In The Standard Edition of the Complete Psychological Works of Sigmund Freud, 12:218-26. London: Hogarth Press.

Gatner, D. T., K. S. Douglas, and S. D. Hart. 2016. 'Examining the Incremental and Interactive Effects of Boldness with Meanness and Disinhibition within the Triarchic Model of Psychopathy'. Personality Disorders: Theory, Research, and Treatment 7 (3): 259-68.

Gravetter, F., and L. Wallnau. 2014. Essentials of Statistics for the Behavioral Sciences. 8th ed. Belmont, cA: Wadsworth.

Hausman, A. 2000. 'A Multi-Method Investigation of Consumer Motivations in Impulse Buying Behavior.' Journal of Consumer Marketing 17 (5): 403-26.

Hofmann, W., M. Luhmann, R. R. Fisher, K. D. Vohs, and R. F. Baumeister. 2014. 'Yes, But Are They Happy? Effects of Trait Self-Control on Affective Well-Being and Life Satisfaction.' Journal of Personality 82 (4): 265-77. 
Houston, R. J., M. S. Stanford, N. R. Villemarette Pittman, S. M. Conklin, and L. E.

Helfritz. 2003. 'Neurobiological Correlates and Clinical Implications of Aggressive Subtypes.' Journal of Forensic Neuropsychology 3 (4): 67-87.

Iyer, G. R., M. Blut, S. H. Xiao, and D. Grewal. 2020. 'Impulse Buying: A Meta-Analytic Review.' Journal of the Academy of Marketing Science 48 (3): 384-404.

Jalees, T. 2009. 'An Empirical Analysis of Impulsive Buying Behavior in Pakistan.' International Review of Business Research Papers 5 (6): 298308.

Kacen, J. J., and J. A. Lee. 2002. 'The Influence of Culture on Consumer Impulsive Buying Behavior.' Journal of Consumer Psychology 12 (2): 16376.

Kesić, T., and I. Kursan. 2008. 'Marketing in Contemporary World.' Tržište 20 (1): 49-6o.

Lange, F., A. Wagner, A., Mueller, and F. Eggert. 2017. 'Subscales of the Barratt Impulsiveness Scale Differentially Relate to the Big Five Factors of Personality' Scandinavian Journal of Psychology 58 (3): 254-59.

Ljubin Golub, T., and K. Sokić. 2016. 'The Relationships between Triarchic Psychopathic Traits and Value Orientations in Men and Women.' Psihološka istraživanja 19 (2): 185-203.

Mao, T., W. Pan, Y. Zhu, J. Yang, Q. Dong, and G. Zhou. 2018. 'Self-Control Mediates the Relationship between Personality Trait and Impulsivity'. Personality and Individual Differences 129:70-5.

Mihić, M., and I. Kursan. 2010. 'Assessing the Situational Factors and impulsive buying Behavior: Market Segmentation Approach.' Management 15 (2): 47-66.

Muruganantham, G., and R. S. Bhakat. 2013. 'A Review of Impulse Buying Behavior.' International Journal of Marketing Studies 5 (3): 149-6o.

Patton, J. H., M. S. Stanford, and E. S. Barratt. 1995. 'Factor Structure of the Barratt Impulsiveness Scale.' Journal of Clinical Psychology 51 (6): 768-74.

Rohan, M. J., and M. P. Zanna. 2001. 'Values and Ideologies.' In Blackwell Handbook of Social Psychology: Intraindividual Processes 1, edited by A. Tesser, N. Scwartz, 458-78. Oxford: Blackwell.

Rokeach, M. 1973. The Nature of Human Values. New York: Free Press.

Rook, D. W. 1987. 'The Buying Impulse.' Journal of Consumer Research 14 (2): 189-99.

Rook, D. W., and R. J. Fisher. 1995. 'Normative Influences on Impulsive Buying Behavior.' Journal of Consumer Research 22 (3): 305-13.

Schwartz, S. H. 1992. 'Universals in the Content and Structure of Values: Theoretical Advances and Empirical Tests in 20 Countries.' In Ad- 
vances in Experimental Social Psychology, vol. 25, edited by M. Zanna, 1-65, New York: Academic Press.

Schwartz, S. H. 1994. 'Are There Universal Aspects in the Content and Structure of Values?' Journal of Social Issues 50 (4): 19-45.

Schwartz, S. H. 1996. 'Value Priorities and Behaviour: Applying a Theory of Integrated Value Systems.' In The Psychology of Values: The Ontario Symposium, vol. 8, edited by C. Seligman, J. M. Olson, and M. P. Zanna, 1-24. Manhwah, NJ: LEA.

Schwartz, S. H., and W. Bilsky. 1990. 'Toward a Theory of the Universal Content and Structure of Values, Extension and Cross-Cultural Replications.' Journal of Personality and Social Psychology 58 (5): 878-91.

Shakaib F. D., and M. Ali. 2018. 'Effects of Personality on Impulsive Buying Behavior: Evidence from a Developing Country.' Marketing and Branding Research 5 (1): 31-43.

Shehzadi, K., M. Ahmad-ur-Rehman, A. M. Cheema, and A. Ahkam. 2016. 'Impact of Personality Traits on Compulsive Buying Behavior: Mediating Role of Impulsive Buying.' Journal of Service Science and Management 9 (5): 416-32.

Sokić, K., and T. Ljubin Golub. 2019. 'Exploring the Role of Boldness in The Triarchic Psychopathy Model.' Psihološka istraživanja 22 (1): 135-52.

Sokić, K., Đ. Horvat, Đ., and I. Krakan. 2019. 'Hexaco Personality Traits as Predictors of Impulsive Buying in Men and Women.' In Interdisciplinary Management Research 15 Conferences' Proceedings, 621-36. Opatija: J. J. Strossmayer University of Osijek.

Tan, K., A. M. Jarnecke, and S. C. South. 2017. 'Impulsivity, Communication, and Marital Satisfaction in Newlywed Couples.' Personal Relationships 24 (2): 423-39.

Verplanken, B., and A. Herabadi. 2001. 'Individual Differences in Impulse Buying Tendency: Feeling and No Thinking.' European Journal of Personality 15 (1): S71-s 83 . 


\section{Analysis of Collaboration between Enterprises and Public Research Organisations \\ on Co-Financed Research-and-Development Projects}

Tina Žitko

University of Primorska, Slovenia

tinazitko@gmail.com

Borut Likar

University of Primorska, Slovenia

borut.likar1@guest.arnes.si

Collaboration between enterprises and public research organisations (PROS) is an important factor in the economic performance and development of a country. The said relates to the objective of the present study, in which we identified the effects, results, reasons for (non-)collaboration, and advantages/disadvantages of collaboration among enterprises and PROS from the perspective of enterprises and business clusters. Our results show that the reason behind enterprises and PROS working together is to achieve breakthrough results rather than financial gain. The obstacles hindering such university-industry collaboration include red tape, inadequate staff, low financial incentives, unawareness of calls for projects, and lack of initiative on behalf of Pros in establishing contacts. Among the most important effects of such collaboration are entry into new markets, progress in the field of human resources, and establishment of new partnerships. Less important effects include the establishment of start-ups and profits arising from patents and licenses. While the development of new products/services and their offer on the market are considered important, scientific achievements and granted patents are regarded as less significant results. University-industry cooperation should thus be improved by way of more frequent collaborations, knowledge exchange, liaison officers, streamlined administration, proper management of intellectual property rights, and increased public visibility.

Key Words: enterprises, PROs, collaboration, transfer of knowledge, business clusters

JEL Classification: 032

(c) BY-SA $\mathrm{https://doi.org/10.26493/1854-6935.18.211-236}$ 


\section{Introduction}

In this qualitative study we investigated how collaboration between enterprises and PROS on joint (Co-)financed R\&D projects (also through liaison institutions) affects their business performance and efficiency. This is influenced not only by financial resources, but also by human expertise, more advanced technology, R\&D, and enterprise strategy (Fatur and Likar 2009). The main feature of $\mathrm{R} \& \mathrm{D}$ is that it is implemented to create new knowledge, which is also the main result of its activities. Acquired knowledge can be focused on generating economic benefits, addressing societal challenges, or simply on generating knowledge per se (Organisation for Economic Co-Operation and Development 2015, 25). R \& D takes place in the form of basic and applied research, pre-competitive and industrial research and in the form of knowledge transfer ('Zakon o raziskovalni in razvojni dejavnosti' 2006). Therefore, we consider it important that the field of R\&D develops and expands especially attentively. In particular, human resources management, development and introduction of innovative technologies, management of intellectual property rights and (not only financial) investments in $\mathrm{R} \& \mathrm{D}$ are at the forefront.

We thought it sensible to analyse the topic in order to determine how (or if) the state's financial incentives aimed at fuelling R \& D affect the efficiency and effectiveness of collaboration between enterprises and public research organisations (hereinafter PROS) as the recipients of such incentives. We were interested in whether these enterprises are more successful and faster in developing and introducing new technologies and whether they are more capable of translating the results of (co-)financed R \& D projects into successful market products. Our interest was focused on the analysis of the effects of state subsidies in terms of enterprise size (micro and small, medium and large enterprises) and level of technological development (low-to-medium-tech enterprises, high-tech enterprises), whereby we observed the role of liaison institutions as an important link between enterprises and PROS. Furthermore, we paid special attention to the analysis of motives and reasons for (non-)collaboration between enterprises and Pros, and tried to determine the advantages, disadvantages, and results of these connections and formulate suggestions for their improvement.

The following paper is divided into sections; first, by way of reviewing and studying foreign and national professional literature and relevant online and other sources, we formed theoretical starting points and ex- 
plained the key concepts for the empirical part of the paper and analysis. In the empirical part of the research, which was conducted between October 2019 and March 2020, we described the methodology of work and sampling, while in the final analysis we presented the main obtained data in tables and additionally (also personally) interpreted them in the accompanying text. In summary, recommendations to companies and business clusters for further participation in joint $\mathrm{R} \& \mathrm{D}$ projects are presented.

The most important and significant contribution of this paper addresses the problem of efficient cooperation between PROs and industry. We focused on different aspects of cooperation, which will be presented. We will also tackle the main obstacles and key success factors for fruitful and long-term based cooperation.

\section{Theoretical Background}

RESEARCH AND DEVELOPMENT (R\&D)

Stanovnik and Uršič (2019) and Rodica, Vojnović, and Grujić (2014) state that $\mathrm{R} \& \mathrm{D}$ is the basis for promoting the technological development, competitiveness and innovativeness of individual enterprises and economies while the said $\mathrm{R} \& \mathrm{D}$ is also indirectly responsible for economic growth of individual enterprises and economies. In this context, the focus is on human resource management, development and introduction of innovative technologies, management of intellectual property rights, transfer of knowledge from public research organisations to the industry and vice versa, and (not only financial) investments in R\&D.

KNOWLEDGE TRANSFER BETWEEN BUSINESS SECTOR AND PROS

As pointed out by Likar ('Borut Likar: če ti v Sloveniji enkrat ne uspe, si že »luzer«' 2018), the willingness of enterprises to collaborate with competing enterprises as well as with partners from outside the industry, such as public research organisations (PROS), is an important factor in their viability and competitiveness. Henttonen, Kianto, and Ritala (2016) cite several authors when defining the term 'knowledge transfer' and they interpret knowledge transfer as the transfer of one's knowledge from that intended for an organisation into collective knowledge. While Lee et al. (2010) emphasise that knowledge exchange must benefit both the individual and the group; Hsu (2008) extends this definition with the condition that the process of knowledge transfer from the holder to the recipient 
allows for an enhanced and more effective work performance. It does not matter whether the knowledge transfer is intentional or unintentional, as long as there is a genuine interest in the transfer on both sides. Moreover, its speed and quality as well as continuity are also important factors. This results in increased knowledge value, along with continuous generation of new knowledge, which in turn advances innovation (Heisig et al. 2016).

\section{BUSINESS CONNECTIONS AND TECHNOLOGY TRANSFER OFFICES}

In Slovenia, technology transfer offices (hereinafter T TOS) in PROs are important agents in knowledge transfer and represent the link between enterprises and PROS. Their range of activities include preparation and placement of the researchers employed at PROS who are active in technological and market-relevant fields to work in enterprises in accordance with their needs and the needs of the industry. An important task of т т O is encouraging enterprises to extend the use of their services into facilitating access to knowledge and research equipment provided by PROs ( $\mathrm{Pal}$ 2017). т тоs therefore represent an adequate and suitable link between enterprises and PROs; however, in a survey conducted among 63 researchers at 22 universities in Ireland, New Zealand, and the United States, O'Kane et al. (2015) show that not even researchers themselves are familiar with the operation of such offices within colleges and faculties, which leads us to question the extent to which enterprises are aware of such services.

Stare, Bučar, and Udovič (2014) examine the results of connections between PROS and enterprises in Slovenia on the case of cooperation between enterprises and PROS through connecting institutions and find that setting common goals for enterprises and PROs facilitates cooperation, increases mutual trust, creates indirect knowledge and intangible capital, which is crucial for long-term cooperation, while also enabling the development of competent personnel and strengthening interdisciplinarity. Moreover, the share of high-tech products in exports and services based on more advanced skills are significantly strengthened. The importance of business clusters is also demonstrated by Strašek, Pušavec, and Likar (2020), who find that strategic partnerships increase the level of open innovation and bring about concrete economic and other nonfinancial effects. In this, it is necessary to take into account the specificities of monitoring the effects of business clusters, which need to be addressed through approaches different from those used for enterprises. This field 
is addressed in more detail by the monograph edited by Bučar, Črnigoj, and Lipnik (2020).

\section{COLLABORATION BETWEEN ENTERPRISES AND PROS}

According to Johnson and Tilley (1999), the first step towards a successful collaboration between a PRO and an enterprise is awareness of the existence of those PROs which are relevant to the business activity the enterprise is engaged in. It is necessary for the enterprise to recognise the importance of knowledge a PRO may contribute to its progress and development, and as pointed out by Zajc (2012), the reputation of a PRO within the economy and its marketing activities are of great importance as well. Furthermore, the first contact of an enterprise with a PRO depends on the level of formality or casualness of either party, and the approach chosen for the first contact may influence the climate of the entire collaboration. The same author (Zajc 2012) and Busom and Fernandez-Ribas (2008) note that larger companies often collaborate with PROs. The reason for this is that they have more resources (financial and human) which they can devote to such cooperation. Large enterprises should therefore be more aware of the benefits of working with capable P ROs. In terms of the degree of technological development, it is high-tech enterprises which should prioritise collaboration with PROS, as this creates a more complex business environment.

\section{Motives for Collaboration}

Perkmann, King, and Pavelin (2011) point out that enterprises and PROS cooperate for a variety of reasons. In the context of such collaboration, PROS primarily seek to gain additional resources for collaboration and make such cooperation conditional on the complementarity of their academic work with the industry they wish to collaborate with. Enterprises, on the other hand, seek access to academic and professional knowledge offered by the PROs, and primarily wish to develop new products or services with their help and experience in $\mathrm{R} \& \mathrm{D}$. The same authors (2011) also note that the more reputable the PRO, the sooner an enterprise decides to enter into such collaboration.

Through a survey on the case of Germany and France, Robin and Schubert (2013) find that cooperation between enterprises and PROs significantly strengthens innovation at enterprises. Lesjak (2019) focuses on the social effects of cooperation between enterprises and PROs, emphasising the importance of knowledge which PROs provide to enterprises for 
$\mathrm{R} \& \mathrm{D}$ purposes and vice versa. The author also finds that the possibility of sharing technological equipment is an important factor of cooperation, that cooperation based on co-funded projects is often the entry point into niche areas of technology, and that publicly accessible research articles can support industry as well as start-ups.

\section{Reasons for Non-Collaboration}

Zajc (2012) further notes that one of the reasons for the lack of cooperation between enterprises and PROs may be a lower level of educational attainment of enterprise managers (over half of them being secondaryschool graduates). Although they are familiar with the PROs they could collaborate with, their lack of previous contact with these institutions means they have no suitable acquaintances or interlocutors within the institution. The same author (2012) concludes that enterprises with no prior experience of such collaboration are less likely to recognise the need to connect with PROS. In a study examining why PROs in Italy (do not) choose to work with enterprises, Tartari and Breschi (2012) state that as the factor which hinders cooperation the most is the fact that PROs fear losing intellectual freedom. Enterprises and PROs expect collaboration to bring about certain benefits. These benefits, as listed by Ankrah et al. (2012), include: financial/economic advantages (joint development is cheaper than individual development, government incentives in the form of subsidies and tax exemptions are easier to obtain (as well as more substantial), organisational advantages (e.g., mutual exchange of staff and establishment of spin-offs and start-ups) and social benefits (references of such cooperation increase both entities' social responsibility, resulting in economic and social progress of the environment both entities are located in, while joint academic publications contribute to increased reputation of companies and PROS).

\section{Barriers for Collaboration}

Pronk et al. (2015) identify various barriers which may make it difficult for PROS and enterprises to collaborate. These relate to the protection of intellectual property, being limited in setting priorities, and incompatibility of interest (education against commercial interests), limited (or too much) time required for collaboration, inflexibility of an entity, limited competence and (lack of) ability to cooperate with other partners. Muscio and Vallanti (2014) supplement this list of barriers with a potential mismatch of incentives between enterprises and PROs (one entity may 
be more motivated to collaborate than the other), lack of suitable intermediaries (as well as levers and comprehensible procedures) in the two entities, which may lead to problems in interaction and networking, and a mismatch between the academic objectives of researchers and the actual business needs of enterprises.

\section{SITUATION IN SLOVENIA}

Countries which invest heavily in $\mathrm{R} \& \mathrm{D}$ are more competitive in the marketplace than those which invest less, and their performance in various sectors (health, transport, digitisation, environment, energy, social services, etc.) helps build a better society (European Commission 2014).

$\mathrm{R} \& \mathrm{D}$ in Slovenia is carried out by research organisations or private researchers in the form of programmes and projects in accordance with the 'Resolution on the Research and Innovation Strategy of Slovenia 20112020' (ReRISS). The aim of the strategy is to facilitate a higher quality of life for all, while achieving higher value added per employee, achieving a higher share of technological and non-technological innovations, providing more quality jobs and thus raising the competitiveness of the economy (Reriss).

The latest available report on the implementation of ReRIss for the 2015-2017 period (Vlada Republike Slovenije 2019) provides findings on the implementation of key success factors (management of research and innovation system, investment in science and innovation, human resources, open, excellent and attractive system, research efficiency innovation activities and effects on the economy), which are not encouraging for the further development of $\mathrm{R} \& \mathrm{D}$ in Slovenia. Compared to the situation before the adoption of the RerIss (before 2011), Slovenia has deteriorated its research and innovation position in the European Union (EU) during its implementation period, despite different commitments. According to the Office of the Republic of Slovenia for Macroeconomic Analysis and Development (Urad Republike Slovenije za makroekonomske analize in razvoj 2019), Slovenia ranks in the group of strong innovators according to the European Innovation Index (EII) within the Central European Member States, although lagging behind the average in 2010-2017.

According to the latest data from the World Economic Forum (Schwab 2019), in 2018, Slovenia ranked 28th in terms of innovation and 27th among 141 countries recorded in statistics. Hence, Slovenia appertains to the group of innovative 'follower' countries, i.e. countries that lag behind 
other countries in terms of innovation results. In 2019, according to the global innovation index, Slovenia ranked 32nd among 131 countries surveyed, which is one place lower than in the preceding year (Dutta, Lanvin, and Wunsch-Vincent 2019).

The reasons behind this situation may be found in the decrease in funding for R\&D (Vlada Republike Slovenije 2019, 154-5) as gross domestic R \& D in Slovenia in 2018 according to final data, amounted to EU R 892.7 million, which is $11.3 \%$ more than in 2017 (Statistični urad Republike Slovenije 2020). However, Slovenia has moved away from the common European goal. In the 2010 strategy 'Europe 2020: A Strategy for Smart, Sustainable and Inclusive Growth' (European Commission 2010), the EU aimed at allocating $3 \%$ of its GDP to R \& D by 2020 ( $1 \%$ to publicly funded and $2 \%$ to privately funded $\mathrm{R} \& \mathrm{D}$ ). According to the Statistical Office of the Republic of Slovenia (Statistični urad Republike Slovenije 2020 ), Slovenia allocated only $2 \%$ of its GDP to R\&D in 2018 . The majority of R\&D funding came from the business sector (1.4\% of GDP allocated to $\mathrm{R} \& \mathrm{D})$.

Investments in $\mathrm{R} \& \mathrm{D}$ are also key to the success, innovation and competitiveness of companies. Results from research which was conducted by Carboni (2017) showed that enterprises which receive public aid invest more in $\mathrm{R} \& \mathrm{D}$. In order to establish the competitiveness of companies, the competent institutions (SPIRIT Slovenia, the Slovenian Enterprise Fund and SID Bank with the support of MGRT) are tendering grants. The aim of these tenders is to integrate the Slovenian economy into international scientific research programmes, create new jobs, promote innovation practices and create innovation infrastructure (Ministrstvo za gospodarski razvoj in tehnologijo Republike Slovenije 2019).

Based on her own research, Krošelj (2019) set out the effects of the P2 subsidy (a subsidy from the Slovenian Entrepreneurship Fund for the launch of innovative projects) on the company's business performance and the number of jobs. The author conducted the research on the basis of a comparative analysis of secondary data. It included 280 companies in the sample, of which 130 were subsidised companies and 150 companies did not receive a subsidy. The performance of companies was determined on the basis of the financial indicator of value added per employee and the number of jobs in relation to the amount of the subsidy received. She studied the data over a period of one year before receiving the subsidy and three years after receiving the subsidy. The results showed that the amount of the subsidy was not positively related to the growth of the com- 
pany's performance, which was measured by value added per employee, and the amount of the subsidy was not positively related to job growth. This means that the performance of companies is influenced not only by financial resources, but also by people's knowledge, more advanced technology, research and development, company strategy and more.

\section{Methodology}

This study presents and interprets the data obtained in the period between October 2019 and March 2020, when we conducted a qualitative examination and analysis of cooperation between enterprises and PROS on joint (co-)financed $\mathrm{R} \& \mathrm{D}$ projects. Two questionnaires consisting of approximately 20 questions were prepared; the first one was administered to a non-random sample of subjectively selected Slovene enterprises, and the second one was administered to business clusters, which were selected in the same manner and which represent an important link between enterprises and PROS. It was their views that we were particularly interested in. In terms of size, the enterprises were classified into as large, mediumsized and micro/small enterprises and as low-to-medium-tech and hightech in terms of technological development - we mainly looked for those who received assistance in the form of public funding. According to their size and level of technological development, the enterprises were divided into matrix groups in order to obtain as evenly distributed data as possible according to the stated features. The minimum number of respondents was estimated at $1-3$.

The data obtained were used to conduct a qualitative analysis according to the presented content sets and according to the matrix (table 1) of the participating enterprises and business clusters. The questionnaires consisted of open-ended as well as close-ended questions. The descriptive data obtained were additionally presented. Where numerical data were obtained, averages were calculated and data were additionally interpreted. Table 1 shows the division by level of enterprise according to their size and technological development, the abbreviations used, the number of respondents included in the analysis, and the illustration and number of business clusters included.

The questionnaire included closed and open-ended questions. In case of the former, the respondents were offered a certain number of answers to choose from, with answers limited to only one possible answer, or were asked to sort the provided answers by order of importance. We obtained numerical data, for which we calculated the averages and provided a de- 
TABLE 1 Illustration of Examined Enterprises

\begin{tabular}{|c|c|c|}
\hline \multirow[t]{2}{*}{ Size of enterprise } & \multicolumn{2}{|c|}{ Technological development } \\
\hline & High-tech enterprises & $\begin{array}{l}\text { Low-to-medium technology } \\
\text { enterprises }\end{array}$ \\
\hline Micro enterprise & $\begin{array}{l}\text { Micro/small-sized high-tech } \\
\text { enterprise (ME-H T), } n=13\end{array}$ & $\begin{array}{l}\text { Micro/small-sized low-to- } \\
\text { medium technology enterprise } \\
(\text { ME-LMT), } n=4\end{array}$ \\
\hline $\begin{array}{l}\text { Medium-sized } \\
\text { enterprise }\end{array}$ & $\begin{array}{l}\text { Medium-sized high-tech enter- } \\
\text { prise (MSE-HT), } n=6\end{array}$ & $\begin{array}{l}\text { Medium-sized low-to-medium } \\
\text { technology enterprise (MSE- } \\
\text { LMT), } n=11\end{array}$ \\
\hline Large enterprise & $\begin{array}{l}\text { Large high-tech enterprise (LSE- } \\
\text { н T), } n=10\end{array}$ & $\begin{array}{l}\text { Large low-to-medium technology } \\
\text { enterprise (LSE-LMT), } n=3\end{array}$ \\
\hline Business Clusters & & $=8$ \\
\hline
\end{tabular}

scriptive explanation of the results. In open-ended questions, we asked respondents to provide answers at their own discretion, and we asked them for at least three statements. The answers were summarised and further interpreted.

The questionnaire which we designed for enterprises contained 19 questions. It was distributed via an e-mail account (set up specifically for this study) to more than 300 Slovenian enterprises, which we subjectively selected from those listed on the bizi.si website (https://www.bizi.si) depending on their size. Another questionnaire containing 14 questions was sent to a total of 43 business clusters. We also chose these subjectively, as we had a very limited base of potential respondents, so we knew exactly and in advance to whom we were sending the questionnaire. The data on business clusters were obtained from the website of the Chamber of Commerce and Industry of Slovenia - Gospodarska zbornica Slovenije (https://www.gzs.si/) and the website of the Public Agency of the Republic of Slovenia for the Promotion of Entrepreneurship, Internationalization, Foreign Investment and Technology - SPIR I T Slovenija (https://www.spiritslovenia.si/). A total of 55 respondents completed the questionnaires; 47 came from enterprises and 8 from business clusters. We present them separately.

\section{Presentation of Results and Data Analysis}

The first section, entitled Data Analysis - Enterprises, presents and analyses the data obtained through the questionnaire administered to enterprises, and the second, entitled Data Analysis - Business Clusters, 
presents the data obtained from business clusters. In the following paragraphs, we present both in detail. The answers to the questions are organised into meaningful sections, while the results and effects of collaborations are outlined in more detail and followed by the interpretation of responses to other questions which we also asked our respondents.

\section{DATA ANALYSIS - ENTERPRISES}

In the first set of questions, we asked enterprises to specify their size, technological development and classification according to the Standard Qualification of Activities (SQA). We were particularly interested in the share of enterprises participating or having participated with PROS in cofinanced R\&D projects. In terms of size, $36 \%$ identified themselves as a micro/small-sized enterprise, $36 \%$ as a medium-sized enterprise and $28 \%$ as a large enterprise. In terms of technological development, $37 \%$ of enterprises identified themselves as a low-to-medium tech enterprise and $63 \%$ as a high-tech enterprise. According to the SQA, enterprises were most often classified as belonging to the $\mathrm{C}$-manufacturing sector. Over the last 5 years, $65 \%$ of respondents have participated in $\mathrm{R} \& \mathrm{D}$ projects connecting industry with public institutions through (co-)financed projects, while $35 \%$ of respondents have not.

\section{Reasons for Participation}

The next set of questions referred to the reasons and motives of enterprises for (non-)cooperation with PROS. In this context, we were interested in how the respondents chose the PRO they cooperated or had cooperated with. Based on their answers, we concluded that there is no interest on the part of enterprises to collaborate with PROS, nor do they feel the need for such collaboration, and also that they have not found or been aware of suitable calls for projects and cooperation which would suit their interests. They highlighted the unresponsiveness and financial incompatibility on the part of PROs. Notably, enterprises, regardless of their size and technological development, chose as the main reasons for collaborating with PROs those options which they believed would facilitate their own advancement (in terms of development, technology, human resources). We can say that the respondents assessed such long-term reasons for cooperation as more important. Financial benefits, which can be regarded as a short-term effect, were ranked at the bottom of the scale. The answers of all groups of respondents about the ways of selecting the PRO to collaborate with in the context of (co-)financed projects show 
quite uniformly that previous collaborations, acquaintances and previously established relationships are the most common reasons for repeat collaborations between enterprises and PROS.

\section{Benefits, Opportunities and Suggestions for Improvement}

The main questions in the questionnaire addressed the benefits of cooperation, opportunities to improve cooperation, obstacles and suggestions for improvement. Respondents provided answers from their own perspective, as well as from PROs and the state. As the main advantage of cooperation between enterprises and PROs, the respondents mentioned the possibility of acquiring and transferring knowledge from practice into theory and vice versa, the possibility of sharing research equipment, developing new products, and taking advantage of greater funding opportunities. They believed that the state would gain from employment (creation of new high-tech jobs), taxes, as well as general and technological development. The state also welcomes and facilitates the networking between enterprises and PROs and provides funding for such collaborations. Enterprises provided numerous suggestions for improving cooperation with PROs: they wish for more active cooperation with PROS, as this would help extend their expertise from the industry into education and vice versa, encourage innovation within enterprises, aid human resource development in terms of educational structure, and increase the opportunities to connect with other enterprises. Enterprises expect PROS to be more active and show interest in establishing partnerships with industry, to be more interested in transferring knowledge and encouraging innovation in enterprises. PRos could establish partnerships with enterprises on their own and thus acquaint students and young researchers with the actual problems enterprises are faced with. The state could help improve such cooperation by cutting red tape, adjusting legislation, encouraging intense networking pathways, and providing more (and higher) financial incentives (including those aimed towards innovation and entrepreneurship). Enterprises, regardless of their size and technological development, listed similar barriers to working with PROs; they experience too many problems and are overwhelmed by bureaucracy (this was often stated by low-tech enterprises), while (according mainly to high-tech enterprises) PR Os are too slow, devote too little time to joint projects and generally possess (too) little practical knowledge. Enterprises blame the state for excessive bureaucratic requirements, regulations and conditions, and for insufficient competence of staff employed 
TABLE 2 Results of Cooperation between Enterprises and PRO

\begin{tabular}{lc}
\hline A new joint venture was formed & 9.6 \\
Scientific publications and citations & 7.4 \\
Granted patents & 7.3 \\
New business opportunities have opened up & 5.9 \\
We have established a long-term, strategic partnership & 5.4 \\
Our employees have gained additional qualifications & 5.4 \\
We have been invited to establish new project partnerships & 5.2 \\
We have established new business contacts & 4.7 \\
We have established cooperation in the use of R\&D equipment & 4.6 \\
The absorption capacity of the enterprise has increased & 3.8 \\
We have developed new products and offered them on the market & 2.6 \\
\hline
\end{tabular}

NOTES 1 - most important, 11 - least important.

in the areas of cooperation between industry and PROS. Respondents felt that cooperation with PROs lacked networking, cooperation and mutual assistance from all three types of entities (enterprises, PROs and the state), especially in the field of knowledge and human resources; such suggestions for improvement were repeatedly offered by high-tech enterprises. Low-tech enterprises, on the other hand, wish to see improvement in the financial field in particular. All matrix groups proposed a higher level of integration into associations and the need to exploit the potential and purpose of such associations, a more active engagement of PROS in the practical aspects of the industry and the need for PROs to pay attention to the actual needs of enterprises, as well as streamlined tendering processes and more financial resources allocated by the state.

\section{Results and Effects}

The penultimate set of questions in the questionnaire referred to the results and effects of collaborations. Table 2 shows how, on average, respondents ranked the given responses associated with the results of their cooperation with PROs by order of importance. The responses of individual matrix groups showed that the matrix groups were in agreement when determining the most and least significant results; the statement 'We have developed new products and services and offered them on the market' was mostly placed in one of the first three places, and the statement 'A new joint venture has been created' was ranked last or next to last.

In this set of questions, we were also interested in how enterprises de- 
TABLE 3 Achieved Effects of Cooperation with PROS in R\&D Programmes

\begin{tabular}{lc}
\hline New spin-offs and start-ups & 5.5 \\
Entering new markets & 4.1 \\
Change in export volume as a result of R\&D project & 3.7 \\
$\begin{array}{l}\text { Change in value added per employee after the implementation of a co-financed } \\
\text { project }\end{array}$ & 2.4 \\
$\begin{array}{l}\text { Presentation of new more technologically demanding projects } \\
\text { Number of new jobs created and their structure as a result of participation in }\end{array}$ & 2.3 \\
the measure (type, complexity ...) & 2.2 \\
\hline
\end{tabular}

NOTES 1 - most important, 6 - least important.

fined the management and ownership of newly created intellectual property rights (hereinafter IP rights). Respondents, regardless of their size and technological development, defined the management and ownership of the newly created IP rights, which remained in the enterprise or were managed under previous contracts, in a similar way. Respondents were also asked about the achieved level of technological development (hereinafter TD), whereby we found that, on average, enterprises participating in (co-)financed projects achieved all levels of TD (most often TD 6 and TD 9), with high-tech enterprises achieving higher levels of TD than lowtech ones.

Table 3 illustrates how enterprises ranked the effects achieved in cooperation with PROS on (co-)financed projects by order of importance. Based on the data obtained from the matrix groups, we learned that lowtech enterprises gave priority to those options which represented effects in the field of human resources and employment, as they ranked the reasons 'Change in value added per employee after the co-financed project' and 'Number of new jobs and their structure, as a result of participation in the measure (type, complexity, education)' higher than high-tech enterprises. High-tech enterprises, on the other hand, chose 'Presentation of new more technologically demanding projects' as the most important effect. Respondents did not see the effect 'Entering new markets' as important (except LSE-LMT, which ranked it as third), nor did they define the effect 'New spin-offs and start-ups' as insignificant.

Table 4 illustrates how respondents ranked indirect effects of working with PROs by order of importance. The results show that all respondents, regardless of their size and $\mathrm{TD}$, perceive those effects which involve some form of cooperation in the market among themselves or with external 
TABLE 4 Indirect Effects of Cooperation between Companies and PROS

\begin{tabular}{lc}
\hline Revenues from the sale of own patents and licenses before and after the project & 4.7 \\
Volume of purchase of foreign licenses before and after the project & 4.1 \\
Increasing competitiveness & 2.0 \\
Increased trust between R\&D project partners & 2.0 \\
New business collaborations and partnerships & 1.9 \\
\hline
\end{tabular}

NOTES 1 - most important, 6 - least important.

partners as more important indirect effects. The benefit of patents and licenses (own or purchased) was perceived as a less significant indirect effect of collaborating with PROs.

\section{Long-Term Effects}

The last set of questions referred to the cooperation between enterprises and PROs after the completion of (co-)financed projects. Respondents' answers indicate that enterprises which have participated (or are participating) in joint projects with PROS continue this cooperation in the form of new projects and in the form of development and final production of the desired products. In cases when joint projects have been completed, there is also a desire for repeat collaboration and joint product development (strategic partnerships, contractual cooperation, etc.), or at least participation in testing, analysis, etc. Based on the answers given, we can conclude that all respondents have participated in joint projects which lasted for at least one year, some for over 5 years (or even up to 15 years). We were interested in why they had not continued collaborating on subsequent projects; the companies stated that they had not yet completed the existing collaboration with the PRO or that they no longer had the need for such collaboration.

\section{DATA ANALYSIS - BUSINESS CLUSTERS}

The first set of questions was general; we were interested in which business clusters they TD of the enterprises participating in their cluster. Respondents mostly identified themselves as strategic research and innovation partnerships ( $75 \%$ and 6 respondents, respectively), one respondent identified themselves as a cluster (13\%) and one (centre of excellence) as other (13\%). Respondents stated that most of their connections are micro and small enterprises (40.3\%), 24.4\% are medium-sized enterprises, $23.5 \%$ are large enterprises, and $\mathbf{1 2 . 5} \%$ are PROs. High-tech enterprises ac- 
count for a larger share in business clusters, namely a total of $52.3 \%$, while low-tech enterprises account for $47.7 \%$.

\section{Reasons for Participation}

In the second set of questions, we asked about the motives and reasons for cooperation between enterprises and PROs through business clusters. We were interested in the reasons for non-cooperation. Respondents cited 'Perceived technological/R \& D/innovation potential for breakthrough results' as the most important motive for cooperation between PROs and enterprises, and they also considered 'Perceived opportunity to finance joint development' an important motive. They did not regard the motives 'Clearly justified need/opportunity in the international market' or 'Appropriate staff or the lack thereof in the enterprise' as important, while 'Financial benefits' was regarded as an even less important motive for cooperation. Business clusters stated that, in their view, enterprises and PROs did not connect through them due to the complex bureaucracy, burdens on existing staff or lack of suitable and experienced staff (either by enterprises or PROs), fear of disclosure of know-how, unfair competition and insufficient financial resources from the state. They also felt that enterprises were too slow to cooperate and did not trust public institutions, and that the state did not have adequate funding mechanisms in place, which would include the co-creation of strategic documents by enterprises.

\section{Advantages, Opportunities and Barriers to Cooperation}

The third set of questions was aimed at identifying strengths, possibilities for improvement and barriers to cooperation. Respondents stated that cooperation between enterprises and PROs through business clusters was good. They opted for this option in $50 \%$ of all cases. A quarter of the respondents believed that such cooperation was very good, and a quarter stated that it was neither good nor bad. On average, the respondents identified 'Newly established and expanded partnerships' as the most important advantage of cooperation between enterprises and PROS through business clusters. They also considered 'Joint Innovation Activities' to be an important reason for cooperation. They perceived the reasons 'Investments in projects in which various partners participate' and 'Joint activities in the field of exports' as the least important. Respondents stated that the role of business clusters could be improved by giving cluster members priority in calls for projects, making partnerships more in- 
terdisciplinary, and encouraging participation of enterprises in decisionmaking. They emphasised the importance of enterprises in clusters, and stated that associations should emphasise their role as facilitators, and that they should also be able to have access to more co-financing. They proposed decreasing the administrative complexity of project management and introducing a voucher system through an intermediary, greater public visibility and more tax relief. Priority areas should also be considered by the Slovenian Research Agency (A R Rs), and establishing connections with enterprises and mutual cooperation should be set as one of the criteria for obtaining funding. According to the respondents, the weaknesses of connecting enterprises and PROS through business clusters are excessive paperwork, bureaucracy, poor co-financing, and too much theory in writing reports. Business clusters have insufficient influence on the conditions of calls for projects, insufficient integration of horizontal key technologies, operation without a clear focus of content, etc.

\section{Results and Effects of Cooperation}

In the central set of questions, we asked business clusters about the results and effects of the cooperation between enterprises and PROs which take place through them. Table 5 shows the respondents' answers regarding the most and least important results. Respondents ranked the result 'New products and services and their offer on the market' the highest in terms of importance. The least important result of cooperation was 'Cooperation in the sharing of $\mathrm{R} \& \mathrm{D}$ equipment.' Less important results were: 'The creation of a new joint venture, 'Granted patents' and 'Scientific publications and citations.' We find it interesting that the respondents emphasise the importance of long-term cooperation and partnerships, but do not perceive joint ventures and the sharing of equipment (which can also be a form of long-term cooperation) as important.

Table 6 shows the ranking of the achieved effects of cooperation between enterprises and PROS through business clusters. Respondents stated that the effects of cooperation between enterprises and PROs through business clusters with the help of public funds are reflected in the change in value added per employee and in newly opened opportunities in the market. The achieved effects in the field of market, personnel, development or pedagogical cooperation between enterprises and PROs were not identified as significant.

Respondents evaluated 'Increased trust between R\&D project partners' as the most important indirect effect of cooperation between enter- 
TABLE 5 Results of Cooperation between Enterprises and PROS through Business Clusters

Cooperation in the use of $\mathrm{R} \& \mathrm{D}$ equipment 10.0

$\begin{array}{lr}\text { Scientific publications and citations } & 9.8\end{array}$

$\begin{array}{lr}\text { Granted patents } & 8.8\end{array}$

$\begin{array}{ll}\text { The creation of a new joint venture } & 8.5\end{array}$

$\begin{array}{ll}\text { Additional qualifications of employees } & 7.0\end{array}$

$\begin{array}{ll}\text { New project partnerships } & 6.0\end{array}$

New business contacts $\quad 4.5$

More effective implementation of R\&D achievements 3.5

$\begin{array}{ll}\text { New long-term strategic partnership } & 3.3\end{array}$

$\begin{array}{ll}\text { New business opportunities } & 2.8\end{array}$

\begin{tabular}{ll} 
New products and services and their offer on the market & 2.0 \\
\hline
\end{tabular}

NOTES 1 - most important, 11 - least important.

TABLE 6 Achieved Effects of Cooperation between Enterprises and Pros through Business Clusters

New spin-offs and start-ups

Direct effects that PPA can also use elsewhere (pedagogical work, other mar-

keting activities, $\mathrm{R} \& \mathrm{D}$ achievements, etc.)

Number of newly created jobs and their structure as a result of participation in the measure (type, complexity ...)

Change in export volume as a consequence of the R\&D project 3.8

Presentation of new technologically more demanding projects 3.3

Entering new markets $\quad 2.3$

Change in value added per employee after the implementation of a co-financed $\quad 2.0$ project

NOTES 1 - most important, 7 - least important.

prises and PROS. Indirect effects 'Volume of purchase of foreign licenses before and after the project' and 'Revenues from sale of own patents and licenses before and after the project' were seen as the least important. Respondents were also asked about the additional effects of cooperation between enterprises and PROS through business clusters with the help of public funds (compared to the situation where the enterprise and the PRO collaborated independently and not under the auspices of a business cluster). According to them, these are: 'newly formed links between enterprises inside and outside the areas of operation,' 'the emergence 
of collaborative thinking about pilot equipment that benefits the majority' and similar 'participation in applied research at an early stage of development.' Respondents believe that cooperation brings an increase in added value and that a major breakthrough in the field of competencies has been achieved as part of cooperation. Enterprises can achieve better business results, enter new global markets, improve business models, develop faster, and conduct more applied research in cooperation with PROS, who can in turn obtain a larger volume of projects, invest more in $\mathrm{R} \& \mathrm{D}$ activities, while joint consortia have more power of obtaining new projects.

\section{Long-Term Effects}

The last few questions in the questionnaire referred to future cooperation. All respondents stated that the cooperation between themselves, the enterprises and PROS continued even after the completion of (co-)financed projects. Cooperation continues either in the form of new, direct, joint projects or only in the form of collaboration within EU projects. Together, they also take the initiative to legislators, as they believe they can achieve more, the burden-sharing is lower and the overall benefit is greater. Cooperation also continues in the form of counselling offered to members of informal partnerships, exchange of information and in the form of organising regular meetings.

\section{Discussion}

\section{REASONS FOR (NON-)COLLABORATION}

- From the answers of both types of entities, it can be concluded that the types of enterprises which tend to establish partnerships with PROs more often are large enterprises and high-tech enterprises.

- Both enterprises and business clusters identified the achievement of breakthrough results as the main reason for establishing cooperation between Pros and enterprises. The answers of business clusters seem surprising, as they, unlike enterprises, do not assign much importance to human resources and international connections. In our opinion, long-term effects of human resource development and opportunities on the international market in connection with the achievement of breakthrough results lead to progress in enterprise development and competitive edge. 
- Financial benefits were identified by both entities as the least important reason for cooperation.

- Enterprises which had not participated in joint projects with PROS felt that they did not feel the need for such collaboration or did not know of appropriate or suitable calls for projects. We found the answer of one respondent that 'they were not invited to participate' interesting. While this may indicate certain passivity on the part of PROS in establishing contacts with enterprises (the reason 'due to slow response' could also be included into this category), it could also imply that enterprises are not familiar with suitable PROs with which they could establish contacts and consequently enter into collaboration.

- Enterprises also report incompatibility with PROS and even their unresponsiveness, lack of practical knowledge, rigidity and lack of initiative to establish connections with enterprises. Here we see an opportunity for PROs to become more involved in establishing contacts with enterprises. In our opinion, business clusters should take the initiative and encourage their members to cooperate with each other, strive to develop diversely trained staff, help PROs and enterprises in achieving these goals and consequently ensure their integration into the economy.

\section{SHORTCOMINGS, OBSTACLES AND OPPORTUNITIES}

- Both groups of respondents identify similar shortcomings with regard to cooperation between enterprises and PROs, whereby bureaucratic hurdles faced by enterprises stand out.

- Both groups mention unsuitable staff employed by the state and believe that the financial incentives they could jointly obtain are too low. Business clusters believe that the situation could be improved by introducing certain advantages for their members who would benefit compared to non-members (for example, higher financial incentives, tax relief, and joint decision-making in co-creating strategic documents). They also emphasise the more active role of enterprises in collaborating with PROS, which was also pointed out by the enterprises themselves. They are also in favour of more frequent collaborations; however, there should be more initiative from PROs, who could also offer their knowledge in the form of collaboration with students and young researchers. It should be recalled at this point 
that while enterprises call for more cooperation, they do not identify any suitable mechanisms to facilitate such cooperation. Business clusters also believe that the mechanisms and possibilities for connecting enterprises and PROs are insufficiently recognised by the public and therefore call for measures which would remedy this situation. Enterprises are also critical of their own non-inclusion in business clusters.

- According to enterprises, the least important way of establishing connections is through ттоs, which is surprising, as this is their main purpose. Although respondents did not provide any reasons as to why they did not use their help in establishing connections with PROS, we may conclude that the reasons for this may lie in extensive bureaucratic requirements, anonymity and lack of familiarity with their work.

- This is also confirmed by the responses of the enterprises from the first analysis, as the respondents viewed past contacts and personal acquaintances as more beneficial in establishing connections with PROS. It is also evident that many enterprises lack such foundations and are not familiar with the operation of PROS, nor do they have a network of useful acquaintances from the past (the reason for this may lie in the secondary-school level of education of managers). The opinion of enterprises regarding the unsuitable staff they need to deal with when establishing contacts and coordinating cooperation, due to the lack of trust in public institutions as recognised by business clusters, is not surprising. We find it interesting that enterprises list unsuitable staff only on the part of Pros, however they themselves do not recognise a similar situation in their own organisation, which is why we find that incentives (financial, practical, and advisory) aimed at training (employment) of suitable staff would also be welcome in enterprises. Here again, we wish to emphasise the importance and role of business clusters, which we agree are not sufficiently recognised by the public, and we also believe that enterprises in particular are not sufficiently aware of the benefits of membership in clusters.

\section{RESULTS AND EFFECTS}

- Both types of entities view the networking and linking of PROs and enterprises as positive, as it enables progress in innovation and in the exchange and dissemination of knowledge. 
- Both groups of respondents identified the development of new products and services and their offer on the market as the most important results of cooperation between enterprises and PROs. Business clusters emphasised the importance of new business opportunities, long-term collaborations and strategic partnerships, while enterprises considered the creation of joint ventures (i.e., long-term strategic partnerships) to be an insignificant result of cooperation with PROS.

- Both groups of respondents see scientific achievements and granted patents as irrelevant results of such cooperation. At this point, there seems to be a noticeable lack of interest in human resource development both on the part of enterprises and business clusters. Ignoring researchers' scientific achievements and not paying attention to IP rights management can lead to a lack of interest in establishing connections and creating results, as researchers do not make progress in personal development through actual engagement with industry, which can be confirmed by a patent or scientific publication.

- The answers of both groups of respondents show that the most important effects of cooperation between enterprises and PROs relate to employees: increased added value per employee, increased number of new jobs, increased demands in the workplace, and higher educational qualification of employees. However, these effects are recognised as more important only by enterprises, especially medium and low-tech ones. Business clusters, meanwhile, believe that a more important effect of cooperation is entering new markets.

- Both groups of respondents think that an important effect of cooperation is the establishment of new contacts, new partnerships, and increased trust between the two agents, which leads to longer-term cooperation. It is interesting to note that both groups of respondents agree that the long-term effect of establishing start-up and spin-off enterprises is a less significant or insignificant effect of cooperation. They also share the opinion regarding the benefits of patents and licenses (their own or purchased ones). This surprises us mainly when it comes to business clusters, as they rate increased competitiveness as an important effect of cooperation and, conversely, the use of acquired knowledge for educational purposes as an insignificant one. In our opinion, this makes an important contribution to increased 
competitiveness and is part of ensuring innovative development and advanced thinking in enterprises.

- Judging by the answers given by enterprises, they are not sufficiently aware of the importance of IP for innovative business and entering international markets. Business clusters are not helpful in this. They rated cooperation between enterprises and PROs through business clusters as important and beneficial in several aspects; new connections and cooperation mean improved business results and greater progress in the field of competencies. According to the clusters, such cooperation reflects higher investments in development and applied research for both enterprises and PROs, as well as an increased volume of new projects in general.

\section{LONG-TERM EFFECTS}

- After the completion of joint projects, enterprises and PROs undertake repeat collaborations either in the form of new work on projects or in the form of product development and final production. Enterprises also want the help of PROS in the field of analysis and testing. Business clusters help them establish new contacts, submit joint initiatives to legislators, assist with undertaking E $\mathrm{U}$ projects or sustaining the existing collaborations by organising informal meetings. According to enterprises, collaborations with P ROs usually last for the duration of the joint project, while some extend this cooperation to more than 10 years.

\section{Conclusion}

As part of the research, it was found that public investment in $\mathrm{R} \& \mathrm{D}$, in conjunction with PROS, is certainly welcome and has important effects on better innovation, competitiveness and the ultimate successful performance of companies. There is still a lot of room to improve these collaborations, which in turn entails benefit for both actors, especially in the greater involvement of them both, their willingness to participate more often and to exchange broader and different theoretical and practical knowledge. The findings of the research also showed that easing bureaucratic requirements and reducing administration would in many ways contribute to more effective cooperation. At this point, we propose also the education and employment of suitable liaison staff by companies, and on the part of PROS, an appropriate promotion of technology transfer offices. Their role should also be more distinct in explaining the 
importance of intellectual property rights, granted patents and the scientific achievements of the researchers involved, while the importance of acquired new knowledge for the education of future employees should be better recognised. We suggest that companies and business associations consider the importance of spin-off companies and more active involvement in this area of cooperation.

We can conclude that the cooperation between PROs and the economy brings a number of positive effects, which differ slightly between high and low and medium-tech companies, and at the same time there are even more opportunities to improve cooperation or more efficient use of public funds.

\section{Acknowledgments}

Umbrella project: CRP V5-1706 (April 2018-March 2020). Analysis of the efficiency of investments in research and development in Slovenia (AEI$R \& D-S L O)$.

\section{References}

Ankrah, N., T. F. Burgess, P. Grimshaw, and N. E. Shaw. 2012. 'Asking Both University and Industry Actors About Their Engagement in Knowledge Transfer: What Single-Group Studies of Motives Omits.' Technovation 33 (2-3): 50-65.

'Borut Likar: če ti v Sloveniji enkrat ne uspe, si že »luzer «'. 2018. u pbudi, 12 January. https://upbudi.upr.si/si/mnenja/borut-likar-ce-ti-v-slovenijienkrat-ne-uspe-si-ze-luzer

Bučar, M., M. Črnigoj, and A. Lipnik, eds. 2020. Vrednotenje sodelovanja med znanostjo in gospodarstvom. Ljubljana: Založba FDV.

Busom, I., and A. Fernandez-Ribas. 2008. 'The Impact of Firm Participation in R\&D Programmes on R\&D Partnerships.' Science Direct Research Policy 37 (82): 240-57.

Carboni, A., O. 2017. 'The Effect of Public Support on Investment and R\&D: An Empirical Evaluation on European Manufacturing Firms.' Technological Forecasting and Social Change 117 (c): 282-95.

Dutta, S., B. Lanvin, and S. Wunsch-Vincent, eds. 2019. The Global Innovation Index 2019: Creating Healthy Lives - The Future of Medical Innovation. 12th ed. Ithaca, NY: Cornell University; Fountainbleu: INSEA D; Geneva: World Intellectual Property Organisation.

European Commission. 2010. 'Europe 2020: A Strategy for Smart, Sustainable and Inclusive Growth.' со M(2010) 2020 final, European Commission, Brussels. 
- 2014. Open Europe: Policies, Reforms and Achievements in EU Science and Innovation 2014-2019. Luxembourg: Publications Office of the European Union.

Fatur, P., and B. Likar. 2009. Ustvarjalnost zaposlenih za inovativnost podjetja: sistemski vidiki managementa idej kot gradnika uspešne organizacije. Koper: Fakulteta za management.

Heisig, P., O. A. Suraj, A. Kianto, C. Kemboi, G. P. Arrau, and N. F. Easa. 2016. 'Knowledge Management and Business Performance.' Journal of Knowledge Management 20 (6): 1169-98.

Henttonen, K., A. Kianto, and P. Ritala. 2016. 'Knowledge Sharing and Individual Work Performance: An Empirical Study of a Public Sector Organisation.' Journal of Knowledge Management 20 (4): 749-68.

Hsu, I. C. 2008. 'Knowledge Sharing Practices as a Facilitating Factor for Improving Organizational Performance through Human Capital: A Preliminary Test.' Expert Systems with Applications 35 (3): 1316-26.

Johnson, D., and F. Tilley. 1999. 'HEI and SME Linkages: Recommendations for the Future.' International Small Business Journal 17 (4): 66-81.

Krošelj, S. S. 2019. 'Subvencije P2 in uspešnost inovativnih podjetij. Master's thesis, Univerza na Primorskem.

Lee, P., N. Gillespie, L. Mann, and A. Wearing. 2010. 'Leadership and Trust: Their Effect on Knowledge Sharing and Team Performance.' Management Learning 41 (4): 437-81.

Lesjak, D. 2019. 'Measuring Impacts of Science and Research on the Society: Development, Issues and Solutions'. Management 14 (3): 219-36.

Ministrstvo za gospodarski razvoj in tehnologijo Republike Slovenije. 2019. 'Spodbujanje inovacij in tehnološkega razvoja.' http://mgrt.arhiv -spletisc.gov.si/si/delovna_podrocja/tehnoloski_razvoj/spodbujanje _inovacij_in_tehnoloskega_razvoja/

Muscio, A., and G. Vallanti. 2014. 'Perceived Obstacles to UniversityIndustry Collaboration: Results from a Qualitative Survey of Italian Academic Departments.' Industry and Innovation 21 (5): 410-29.

O’Kane, C., V. Mangematin, W. Geoghegan, and C. Fitzgerald. 2015. 'University Technology Transfer Offices: The Search for Identity to Build Legimacy.' Research Policy 44 (2): 421-37.

Organisation for Economic Co-Operation and Development. 2015. Frascati Manual 2015: Guidelines for Collecting and Reporting Data on Research and Experimental Development. Paris: Organisation for Economic Co-Operation and Development.

Pal, L. 2017. 'O pisarnah za prenos tehnologij na slovenskih J Ro.' In Pisarne za prenos tehnologij $v$ Sloveniji, edited by Š. Stres and L. Pal, 16-19. Ljubljana: Združenje profesionalcev za prenos tehnologij Slovenije.

Perkmann, M., Z. King, and S. Pavelin. 2011. 'Engaging Excellence? Effects 
of Faculty Quality on University Engagement with Industry.' Research Policy 40 (4): 539-52.

Pronk, J. T., S. Y. Lee., J. Lievense, J. Pierce, B. Palsson, M. Uhlen, and J. Nielsen. 2015. 'How to Set Up Collaborations between Academia and Industrial Biotech Companies.' Nature Biotechnology 33 (3): 237-40.

'Resolution on the Research and Innovation Strategy of Slovenia 20112020.' N.d. https://www.gov.si/assets/ministrstva/MIZS/Dokumenti/ Zakonodaja/EN/Resolution-on-Research-and-Innovation-Strategy -of-Slovenia_2011-2020.pdf

Robin, S., and T. Schubert. 2013. 'Cooperation with Public Research Institutions and Success in Innovation.' Research Policy 42 (1): 149-166.

Rodica, B., B. Vojnović, and D. Grujić. 2014. 'Raziskovanje inovacijske aktivnosti v slovenskih podjetjih.' Revija za ekonomske in poslovne vede 1 (1): 51-61.

Schwab, K., ed. 2019. The Global Competitiveness Report 2019: Insight Report. Geneva: World Economic Forum.

Stanovnik, P., and S. Uršič. 2019. 'Raziskovalno-razvojna vlaganja kot osnova za tehnološki razvoj v Sloveniji.' Journal of Innovative Business and Management 11 (1): 16-24.

Stare, M., M. Bučar, and B. Udovič. 2014. 'Soustvarjanje znanja med javnimi raziskovalnimi organizacijami in gospodarstvom za povečanje konkurenčnosti.' IB revija 48 (3-4): 53-59.

Statistični urad Republike Slovenije. 2020. 'Na voljo končni podatki o raziskovalno-razvojni dejavnosti (RRD) v 2018.' Statistični urad Republike Slovenije, 2 March. https://www.stat.si/StatWeb/News/Index/8692

Strašek, A., F. Pušavec, and B. Likar. 2020. 'Open Innovation and Business Performance Improvement in Strategic Business Alliances.' Management 25 (1): 133-44.

Tartari, V, and S. Breschi. 2012. 'Set Them Free: Scientists' Evaluations of the Benefits and Costs of University-Industry Research Collaboration.' Industrial and Corporate Change 21 (5): 1117-47.

Urad Republike Slovenije za makroekonomske analize in razvoj. 2019. Poročilo o razvoju 2019. Ljubljana: UMAR.

Vlada Republike Slovenije. 2019. 'Poročilo o uresničevanju Resolucije o raziskovalni in inovacijski strategiji Slovenije za obdobje 2015-2017.' Vlada Republike Slovenije, Ljubljana.

Zajc, M. D. 2012. Soustvarjanje in prenos znanja med malimi in srednjimi podjetji ter raziskovalnimi organizacijami. Ljubljana: Fakulteta za družbene vede.

'Zakon o raziskovalni in razvojni dejavnosti.' 2006. Uradni list Republike Slovenije, št. 61. https://www.uradni-list.si/1/objava.jsp?sop=2006-o12567. 
Sustainable Growth-Environment Nexus in the Context of Four Developing Asian Economies: A Panel Analysis

\author{
Mowshumi Sharmin \\ Bangladesh Institute of Governance and Management, Bangladesh \\ mowshumi.sharmin@bigm.edu.bd \\ Mohammad Tareque \\ Bangladesh Institute of Governance and Management, Bangladesh \\ mohammad.tareque@bigm.edu.bd
}

This paper has used a STIRPAT model to investigate the synergistic effect of $\mathrm{CO}_{2}$ emission, energy consumption, energy intensity, economic growth, population, urbanization and trade openness to demonstrate growthenvironment nexus in four selected developing Asian economies. Taking a panel data set from Bangladesh, China, India and Indonesia this study applies Autoregressive Distributed Lag (ARDL) model and VEC Granger Causality/Block Exogeneity Wald Tests. The empirical results show that energy intensity, urbanization, population, and per capita GDP growth are the raison d'être of $\mathrm{CO}_{2}$ emissions whereas trade openness is found to be negatively related to $\mathrm{CO}_{2}$ emissions. Conversely, energy consumption, urbanization, population and trade openness are positively related to per capita GDP. In addition, it also investigates the Environmental Kuznets Curve (EKC) hypothesis and the findings substantiate an inverted Ushaped relationship. Cross-section short-run coefficients of country-level data are inquired into to check the robustness of the panel outcomes.

Key Words: EKC hypothesis, sTIRPAT model, $\mathrm{CO}_{2}$ emission, urbanization, energy consumption

JEL Classification: C33, O44, Q43

(c) BY.SA https://doi.org/10.26493/1854-6935.18.237-256

\title{
Introduction
}

Anthropogenic pollutant emission due to energy consumption is emerging as an awfully challenging trouble in front of the humankind in the 21st century. The implications of human-induced $\mathrm{CO}_{2}$ emissions to the environment not only change the Earth's eco-system but also change the pattern of technology use, lifestyle, economies, and policy. It is also factual for the four Asian developing economies of this study: Bangladesh, India, 
China and Indonesia. Rapid economic growth has usual association with augmented energy consumption which is responsible for unforeseen effects on the energy source and the atmosphere. Hence, carbon emissions and energy consumption play a decisive role in the contemporary dispute on the environmental conservation and sustainable development issues. Climate change could spring from many environmental issues (viz. anthropogenic pollutants emission from sulfur dioxide, oxides of nitrogen etc.), but this study focuses on $\mathrm{CO}_{2}$ emission related predicament that cause global warming. The Paris Climate Conference 2015 (CO 21) agreement proclaimed limiting emissions following national level environment policies (Rhodes 2016). COP 21 declarations also augment an increase of the study regarding carbon emission, energy consumption, global warming and climate change.

Sustainable development embraces a wide range of social, environmental and economic development issues. This paper strives to address most of them viz. climate change, energy, urbanization and environment. Variables like GDP and trade openness deals with the economic aspect while trade openness exhibits global dimension as well. Energy consumption, $\mathrm{CO}_{2}$ emission addresses the environmental features whereas urbanization and population demonstrates social development aspects. Urban population growth is a process of social transformation and rejuvenation as well.

The rational for selecting the four economies for analysis is that Bangladesh, Indonesia, China and India are remarkable for being the fastest growing promising developing economies in Asia maintaining exceptionally high growth rates $8.15 \%, 5.02 \%, 6.1 \%$ and $6.8 \%$ respectively with rapid urbanization (see http://data.worldbank.org/). China is the world's second largest economy by nominal GDP and largest by purchasing power parity (PPP) and potentially hailed as new superpower. It is the largest $\mathrm{CO}_{2}$ emitter and the leading investor in renewable energy as well. India is the third largest economy by purchasing power parity (P P P). Indonesia is the largest economy in the Southeast Asia and seventh largest in terms of PP P. Bangladesh positioned as one of the next eleven promising markets and third largest South Asian economy. The economic background of Bangladesh and Indonesia are roughly similar as emerging economy and China and India are on the verge of being the superpowers in the global economy. Here arises the apprehension of $\mathrm{CO}_{2}$ emission related global warming with the increase in energy consumption keeping in pace with economic growth. 
Against this background, the main objective of this study is to investigate the impact of per capita energy consumption, per capita GDP, urbanization, population and trade openness on per capita $\mathrm{CO}_{2}$ emission employing a linear STIRPAT model and a non-linear EKC hypothesis in four Asian developing economies from 1980 to 2014. The study will simultaneously analyze another linear model showing the consequence of energy consumption, population, trade openness, urbanization, and $\mathrm{CO}_{2}$ emission on viable economic growth as well.

The study is distinctive because it inquired into the synergy between energy, economy, and social development along with their contribution and relationship to the $\mathrm{CO}_{2}$ emission in the four selected developing Asian economies. In addition, this study also included three separate equations including both linear and nonlinear estimation process taking four countries representing three stages of development. Moreover, not many research works have integrated urbanization variable together with trade openness simultaneously like this study. For instance, only Hossain (2011); Kasman and Selman Duman (2015); Rafiq, Salim, and Nielsen (2016) have taken both the variable and only latter used a non-linear estimation. Hence there is a paucity of non-linear estimation process in this regard which this study attempts to deal with. This paper tries to address the sustainable development issues as well, as it concentrates on environmental quality or degradation (in this case $\mathrm{CO}_{2}$ emission), economic growth and population being the fundamental aspects of sustainable development.

Starting with the introduction in Section 1 above, the remainder of the study is ordered as follows: the existing empirical evidence from the literature is reviewed in Section 2. Section 3 examines the theoretical framework with model specifications; Section 4 represents data sources; Section 5 illustrates econometric methodology. Empirical results are analyzed in Section 6. The final section draws conclusion and policy implications.

\section{Literature Review}

Attention concerning the impact of economic growth on environment is on the rise from the last few decades of the previous century. The empirical findings of Hamit-Haggar (2012) posit that energy consumption has a positive and statistically significant impact on greenhouse gas emissions whereas a non-linear relationship is found between greenhouse gas emissions and economic growth, consistent with the environmental Kuznets 
curve in the long-run. Empirical results for China in the study of Zhang and Cheng (2009) show that neither carbon emissions nor energy consumption leads economic growth. The domino effect from the study of Halicioglu (2009) shows that income is the most significant variable in explaining the carbon emissions in Turkey which is followed by energy consumption and foreign trade and it is further extended into the environmental function of Jalil and Mahmud (2009) and Jayanthakumaran, Verma, and Liu (2012). McGee and York (2018), York (2007) and Cole and Neumayer (2004) have found urbanization encourages $\mathrm{CO}_{2}$ emissions for a group of economies but Chen, Jia, and Lau (2008) and Liddle (2004) have found that upgradation of urbanization along with urban density increases the efficacy of public transport exploitation.

Ample numbers of pragmatic research works has been accomplished since the emergence of the EKC theory. Grossman and Krueger (1991) have examined the ecological outcome of the NAFTA (North American Free Trade Agreement). The study findings have confirmed the inverted$\mathrm{U}$ type association among $\mathrm{SO}_{2}$, dark matter (fine smoke), suspended particles (SPM) and per capita GDP and the findings have been contemporaneously established by Shafik and Bandyopadhyay (1992), Panayotou (1993) and Selden and Song (1994). Holtz-Eakin and Selden (1995) have used global panel data and estimate a log-quadratic relationship from 1951 to 1986 and also found E KC. Galeotti and Lanza (1999) estimate E KC using two alternative parametric functional forms and found invertedU relationships. Friedl and Getzner (2003) have considered the E KC for Austria from 1960 to 1999 , and found an N-shaped relationship with evidence of a structural break in the mid-seventies due to the oil price shock. The study of Martínez-Zarzoso and Bengochea-Morancho (2004) on 22 OECD countries spanning from 1975 to 1998 using a PMG (pooled mean group) method have found an $\mathrm{N}$-shaped correlation preponderance for many countries. Study of Sachs, Panayotou, and Peterson (1999) for panel data for 150 countries from 1960 to 1992, have found an inverted-U shaped relationship explainable by structural changes accompanying economic growth: from agriculture, to industry, to services.

Further, Agras and Chapman (1999) have employed a log-quadratic E KC model with a lagged dependent variable and trade variables, in addition to income applying the ARDL to analyze the dynamic process and wrap up that income has the maximum influence. Al-Mulali, Saboori, and Ozturk (2015) also applied A RDL and provide a review of studies that examined EKC theory taking information from particular economies. They 
have found two types of the EKC corresponding to $\mathrm{CO}_{2}$ emissions. The work of McConnell (1997) has postulated that for EKC, positive sign of income elasticity of demand is not only optional but also inadequate. Andreoni and Levinson (2001) indicate that economies of scale in pollution abatement are sufficient conditions for the existence of the E KC.

The study of Hossain (2011) has included urbanization, $\mathrm{CO}_{2}$ emissions, GDP, energy consumption and trade in his study of nine newly industrialized countries. The result indicates that higher energy consumption gives rise to more $\mathrm{CO}_{2}$ emissions polluting the environment. But in respect of GDP, trade openness and urbanization the environmental quality shows stable association in the long-run. The study of Sharmin (2021) have found $1 \%$ increase in non-renewable energy consumption will increase $\mathrm{CO}_{2}$ emission by on an average more than $0.75 \%$. Pao and Tsai (2010) in their study of вRIC countries have found bidirectional causal relationship between pollutant emissions and energy consumption, and GDP and energy consumption in the long run but unidirectional causal relationship between energy consumption and GDP in the short run. Sharma (2011) has found urbanization has a negative and significant impact on carbon emissions for a panel of 69 countries while this impact was identified insignificant if income-level group is considered. Sadorsky (2014) have employed a STIRPAT model to investigate the effect of urbanization on $\mathrm{CO}_{2}$ emissions in 7 emerging economies. Using A RDL model he shows that increase in affluence, population, or energy intensity increase $\mathrm{CO}_{2}$ emissions in the long-run. The study of Sharmin and Tareque (2018) has postulated growth stimulates energy consumption and consequently causes $\mathrm{CO}_{2}$ emissions. VDC result posits that energy intensity, urbanization, industrialization and growth are responsible for more than $60 \%$ of the $\mathrm{CO}_{2}$ emission in the long run.

In pooling together, from the above existing empirical evidence it can be observed that the idea of the nexus is clear though some researchers are differing. The magnitude and the sign of the association of the studies vary depending upon the data set used, countries considered and estimation techniques applied. This study looks into the different dimensions of growth-environment nexus in the context of four most promising economies of Asia now at different stages of development. Moreover, very few studies took both urbanization and trade openness concomitantly. To address the sustainable development issues this study attempts to analyze the synergism among energy, environment, economy, and social development in the four selected developing Asian economies. 


\section{Theoretical Framework}

This study employs the Stochastic Impacts by Regression on Population, Affluence and Technology (stirpat) and EKC model, panel cointegration technique, and dynamic PMG/ARDL (Autoregressive Distributed Lag) estimator (Pesaran, Shin, and Smith 2001) to determine the influence of GDP growth, energy consumption, energy intensity, population, trade openness and urbanization on $\mathrm{CO}_{2}$ emissions for four Asian developing economies.

STIRPAT which is a stochastic adaptation of the IPAT form is an acknowledged method employed to study the nexus between population and environment (Dietz and Rosa 1997). STIRPAT follows the IPAT equation of Ehrlich and Holdren (1971). IPAT form postulates environmental impacts can be found by multiplying population, affluence and technology. It takes the form:

$$
I=P \times A \times T,
$$

where $I$ denotes environmental impact, $P$ indicates population, $A$ is affluence or consumption per capita (GDP per capita), and $T$ is technology or impact per unit of consumption. Affluence is typically operationalized as per capita gross domestic product (GDP) so that $T$ is the impact per unit of economic activity. The criticisms of the Ehrlich-Holdren's IPAT framework are that it does not authorize hypothesis testing, and it presumes a stiff proportionality between factors. Dietz and Rosa (1997) addressed those two criticisms by proposing a stochastic version of IPAT:

$$
I_{i t}=a_{i} P_{i t}^{b} A_{i t}^{c} T_{i t}^{d} e_{i t},
$$

where the subscript $i(i=1, \ldots, N)$ symbolizes countries, and $t(t=$ $1, \ldots, T)$ refers to time period, $a$ is the constant and exponent $b, c$, and $d$ are to be estimated, and $e$ denotes the residual error term.

The three-way associations among the variables of this study are empirically examined by using the following three simultaneous equations. In model specification, the first model (Model I) investigates the association among $\mathrm{CO}_{2}$ emissions, GDP growth, energy intensity, population, urbanization and trade openness. The model (I) is expressed as follows:

$$
\begin{aligned}
\operatorname{Ln}\left(C O_{2 i t}\right)= & \alpha_{\mathrm{o}}+\alpha_{1 i}\left(\operatorname{Ln} Y_{i t}\right)+\alpha_{2 i}\left(\operatorname{LnEI} I_{i t}\right)+\alpha_{3 i}\left(\operatorname{Ln} P_{i t}\right) \\
& +\alpha_{4 i}\left(\operatorname{Ln} U_{i t}\right)+\alpha_{5 i}\left(\operatorname{LnTO}_{i t}\right)+\varepsilon_{i t},
\end{aligned}
$$

where $\mathrm{CO}_{2}$ is per capita pollutant emissions, $Y$ is GDP per capita (affluence), $E I$ is energy intensity, $P$ is total population, $U$ is urbanization and 
TO is trade openness. Here $\varepsilon$ refers to particular error symbol, the subscript $i$ denotes countries and $t$ stands for time. These symbols are synonymously used in equation (5).

Another model (Model II) has looked into the impact of $\mathrm{CO}_{2}$ emissions, energy consumption, population, urbanization and trade openness on economic growth:

$$
\begin{aligned}
\operatorname{Ln}\left(Y_{i t}\right)= & \gamma_{\mathrm{o}}+\gamma_{1 i}\left(\operatorname{LnCO}_{2 i t}\right)+\gamma_{2 i}\left(\operatorname{LnEC} C_{i t}\right)+\gamma_{3 i}\left(\operatorname{Ln} P_{i t}\right) \\
& +\gamma_{4 i}\left(\operatorname{Ln} U_{i t}\right)+\gamma_{5 i}\left(\operatorname{LnTO} O_{i t}\right)+\varepsilon_{i t},
\end{aligned}
$$

where $\mathrm{CO}_{2}$ is per capita pollutant emissions, $Y$ is GDP per capita (affluence), $E C$ is per capita energy consumption, $P$ is total population, $U$ is urbanization and TO is trade openness. Here $\varepsilon$ refers to idiosyncratic error term, the subscript $i$ denotes countries and $t$ is time.

In EKC model (Model III), a logarithmic form of per capita GDP squared is included to find out the possibility of an EKC assumption for the stipulated four economies. According to the theory, economic growth exhibits no threat but directs to environmental improvement at the higher stage of income intensity. Coefficients of non-linear models with GDP per capita squared directly demonstrate the turning point of income, where emissions are maximum. This study tries to find more precise estimators of the coefficients to observe the presence of an EKC in four Asian economies. The EKC model of this study is formulated as follows:

$$
\begin{aligned}
\operatorname{Ln}\left(C O_{2 i t}\right)= & \beta_{\mathrm{o}}+\beta_{1 i}\left(\operatorname{Ln} Y_{i t}\right)+\beta_{2 i}\left(\operatorname{Ln} Y_{i t}^{2}\right)+\beta_{3 i}\left(\operatorname{LnEI_{it}}\right) \\
& +\beta_{4 i}\left(\operatorname{Ln} P_{i t}\right)+\beta_{5 i}\left(\operatorname{Ln} U_{i t}\right)+\beta_{6 i}(\operatorname{LnTO} i t)+\varepsilon_{i t} .
\end{aligned}
$$

Theoretical expectations of the three models are:

$$
\begin{aligned}
& \text { Model I, } \alpha_{1}>0 ; \alpha_{2}>0 ; \alpha_{3}>0 ; \alpha_{4}>0 ; \alpha_{5} \gtrless 0 \\
& \text { Model II, } \gamma_{1}>0 ; \gamma_{2}>0 ; \gamma_{3}>0 ; \gamma_{4}>0 ; \gamma_{5} \gtrless 0 \\
& \text { Model III, } \beta_{1}>0 ; \beta_{2} \gtrless 0 ; \beta_{3}>0 ; \beta_{4}>0 ; \beta_{5}>0 ; \beta_{6} \gtrless 0
\end{aligned}
$$

The models get insight from some earlier studies and strongly follow some preceding studies for instance, Model I and III are inspired by the studies of York, Rosa, and Dietz (2003), Cole and Neumayer (2004), Halicioglu (2009), Hossain (2011), Sadorsky (2014) and Rafiq, Salim, and Nielsen (2016). This study contributes to the existing literature as the study combines these above mentioned approaches but make pertinent modification employing three simultaneous equations for estimation to capture particular features of the stipulated economies. Equation (3) em- 
TABLE 1 Definition and Measurement of the Variables

\begin{tabular}{lll}
\hline Variables & Definition & Measurement \\
\hline $\mathrm{CO}_{2}$ & Per capita carbon emissions & Metric tons per capita \\
$\mathrm{Y}$ & GDP per capita & Constant 2010 US\$ \\
$\mathrm{Y}^{2}$ & Quadratic term of Y & Us\$ per capita squared \\
$\mathrm{EC}$ & Energy use per capita & Kg of oil equivalent per capita \\
$\mathrm{EI}$ & Energy consumption per capita divided & - \\
& by GDP per capita & \\
$\mathrm{U}$ & Urban population growth & Annual \% \\
$\mathrm{P}$ & Total population & - \\
$\mathrm{TO}$ & Share of export import ratio to GDP & Constant 2010 U \$ $\$$ \\
\hline
\end{tabular}

Notes All data are in natural logarithm.

ploys a STIRPAT model and equation (4) intends to see the impact of $\mathrm{CO}_{2}$ emissions, energy consumption, population, urbanization and trade openness on economic growth. Equation (5) looks into the EKC hypothesis.

\section{Data Sources and Diagnostic Tests}

We have used balanced panel dataset of 4 Asian developing economies (Bangladesh, India, China and Indonesia). Annual data for carbon dioxide emissions $\left(\mathrm{CO}_{2}\right)$, energy consumption (EC), energy Intensity (EI), trade openness (TO), per capita real GDP (Y), urbanization (U), and population $(\mathrm{P})$ are taken from the W DI (World Development Indicators) spanning from 1980-2014. The definition and measurement of the variables used in this study are expressed in table 1 . Taking natural logarithm, correlation matrix between variables is demonstrated in table 2 .

Correlation matrix between variables of the four Asian economies of this study shows the highest $\mathrm{CO}_{2}$ emissions correlation (98\%) with energy consumption followed by trade openness (83\%) with per capita GDP and per capita GDP $(75 \%)$ with $\mathrm{CO}_{2}$ emission. $\mathrm{CO}_{2}$ emission correlates negatively with urbanization but has positive correlation with energy consumption, energy intensity, per capita GDP growth, population and trade openness.

\section{Econometric Methodology}

Firstly, we have carried out panel unit root test (PURT) as macroeconomic variables exhibit trends. Therefore, test of unit root is a prerequi- 
TABLE 2 Correlation Matrix

\begin{tabular}{lrrccccc}
\hline Item & $\operatorname{lnCO}_{2}$ & $\ln \mathrm{EC}$ & $\operatorname{lnEI}$ & $\ln \mathrm{Y}$ & $\ln \mathrm{U}$ & $\ln \mathrm{P}$ & $\ln \mathrm{TO}$ \\
\hline $\ln \mathrm{CO}_{2}$ & 1 & & & & & & \\
$\ln \mathrm{EC}$ & $0.986^{*}$ & 1 & & & & & \\
$\ln \mathrm{EI}$ & $0.404^{*}$ & $0.344^{*}$ & 1 & & & & \\
$\ln \mathrm{Y}$ & $0.759^{*}$ & $0.811^{*}$ & $-0.269^{*}$ & 1 & & & \\
$\ln \mathrm{U}$ & $-0.374^{*}$ & $-0.320^{*}$ & -0.094 & $-0.270^{*}$ & 1 & & \\
$\ln \mathrm{P}$ & $0.745^{*}$ & $0.674^{*}$ & $0.762^{*}$ & $0.217^{*}$ & $-0.511^{*}$ & 1 & \\
$\ln \mathrm{CO}$ & $0.495^{*}$ & $0.529^{*}$ & $-0.473^{*}$ & $0.838^{*}$ & $-0.145^{* *}-0.034$ & 1 \\
\hline
\end{tabular}

NOTES ${ }^{*},{ }^{* *}$, and ${ }^{* * *}$ represents statistical significance at the $1 \%, 5 \%$ and $10 \%$ point, correspondingly.

site to address whether there are restrictions on the autoregressive procedure across cross-sections or series. PU R T primarily consists of (i) Firstgeneration techniques, that presume cross-sectional independence (e.g. Maddala and Wu 1999; Choi 2001; Levin, Lin, and Chu 2002; Im, Pesaran, and Shin 2003) with (ii) Second generation techniques, that clearly permit for several sort of cross-sectional dependence (e.g. Pesaran (2007). This paper employs the Levin, Lin and Chu (LLC), Im, Pesaran, and Shin (IPS), A DF - Fisher Chi-square, PP - Fisher Chi-square and Hadri Z-stat tests to check for panel unit root properties.

Secondly, we have employed panel co-integration techniques. If the indicators used for the study are stationary at first difference, co-integration tests in the panel form are applied to find out the long-run equilibrium association amid the non stationary indicators. The existence of a cointegrated relationship between the series exhibits potential long-run connection between the indicators. As the indicators used in the study are integrated of order 1, this paper uses Kao test (Kao 1999) following Engle-Granger methodology and Johansen test in the context of panel unit roots to examine the possible existence of one or more co-integrated relationships among the variables (i.e. indicators).

Thirdly, we have used PMG/ARDL estimator to calculate long-run as well as short-run dynamics among the indicators. If there exists cointegration between the indicators, PMG estimator (Pesaran, Shin, and Smith 1999) are employed for dynamic heterogeneous panels. PMG is employed to examine the causal path connecting dependent and independent indicators as well. In addition PMG model limits the long-run coefficients to remain unchanged but makes the short-run coefficients 
and error variances to differ across countries. Another advantage of this model is that it yields consistent estimates of the long-run parameters irrespective of whether the underlying regressors are stationary, nonstationary or mutually co-integrated (Pesaran, Shin, and Smith 1999).

Finally, vec Granger Causality/Block Exogeneity Wald Tests test in the VЕсм framework is applied to see the short-run causality and significant $\mathrm{t}$-test on a negative ECT to exhibit long-run causality among the variables.

\section{Analysis of Empirical Results}

\section{PANEL UNIT ROOT TEST RESULTS}

This paper uses various econometric tests (Im, Pesaran and Shin W-test, Fisher type tests, Levin, Lin and Chu test, and Hadri test) to check for the existence of a unit root in the panel data set. In all the above tests except for Hadri test, the null hypothesis is that of a unit root. The Wtest is based on the application of the ADF test to panel data, and allows heterogeneity in both the constant and slope terms of the ADF regression (Christopoulos and Tsionas 2003). The panel unit root check outcomes are expressed in table 3 .

Employing pertinent techniques, the study finds that all the indicators used to see the growth environment nexus are stationary at first difference I (1). This paper includes individual intercept, individual intercept and trend, no intercept and no trend in order to minimize the problems arising from cross-sectional dependence. The Schwarz Information Criterion (SIC) is utilized to verify the automatic lag measurement lengthwise. Further, the Bartlett kernel is operated to analyze the long-run variation using LLC technique where Newey-West bandwidth selection algorithm decides the lags.

\section{PANEL CO-INTEGRATION TESTS RESULTS}

Panel co-integration techniques have been employed in this study to portray quicker implication. Still, the question of homogeneity arises. In order to investigate the existence of one or more co-integrated vectors two tests are applied. First, Kao test (Kao 1999) based on Engle-Granger methodology and finally a Johansen test in the context of panel unit roots, to estimate residuals from long run relations. Results of Panel CoIntegration Tests are provided in table 4.

Findings suggest that the null hypothesis of no co-integration is rejected at $5 \%$ level according to the employed co-integration tests. More 


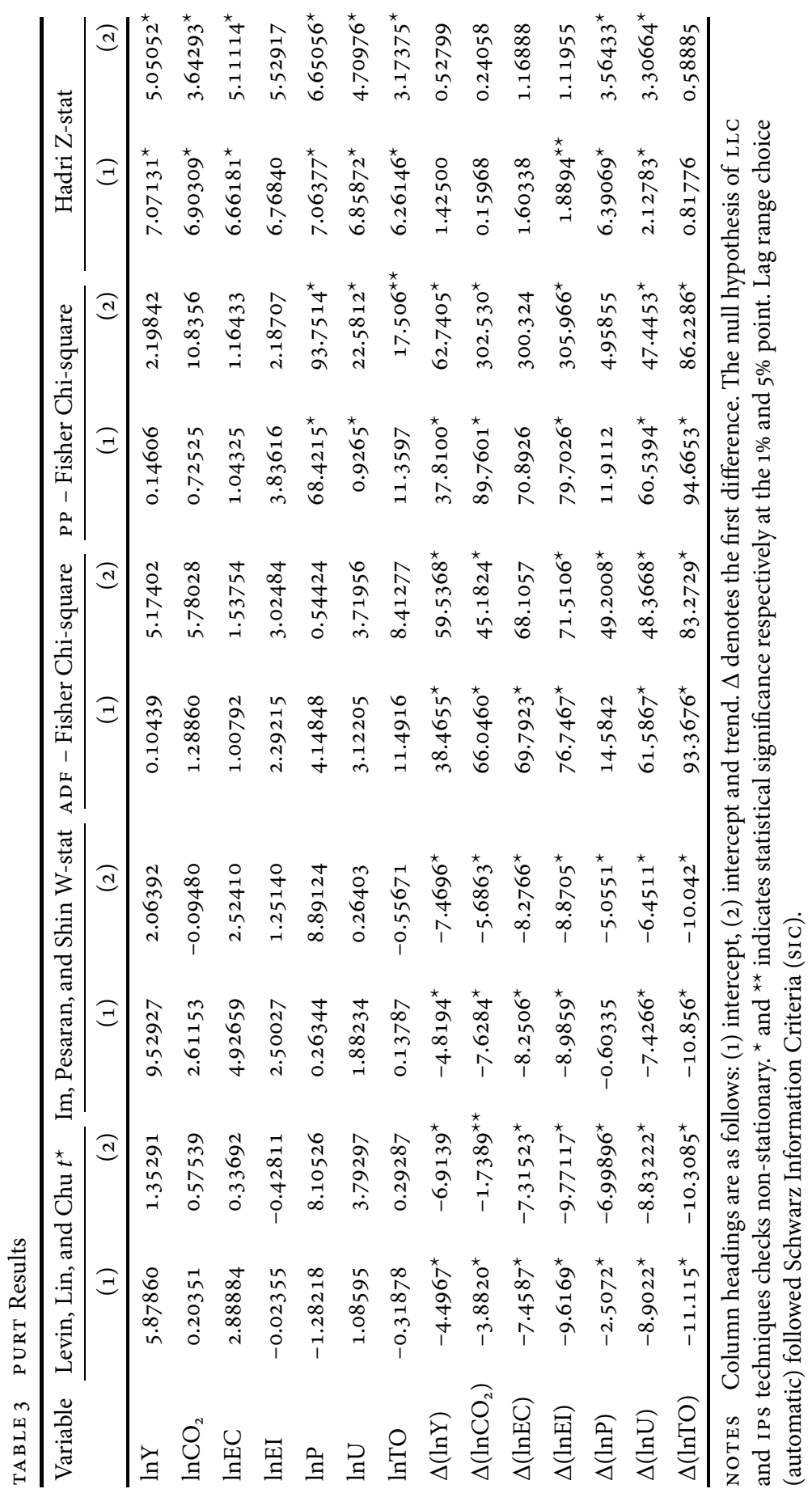


TABLE 4 Panel Co-Integration Tests

\begin{tabular}{|c|c|c|}
\hline Segment & Fisher (combined Johansen) & Kao Test \\
\hline Model I & $\begin{array}{l}\text { (1) } 193.6^{*}[r=0], 100.3^{*}[r \geq 1], 55.96^{*}[r \geq 2], 25.03^{*}[r \geq 3] \text {, } \\
13.00[r \geq 4] \\
\text { (2) } 112.0^{\star}[r=0], 53.22^{\star}[r \geq 1], 38.22^{\star}[r \geq 2], 19.83^{* *}[r \geq 3] \\
9.116[r \geq 4]\end{array}$ & $-2.707493^{*}$ \\
\hline Model II & $\begin{array}{l}\text { (1) } 193.6^{\star}[r=0], 100.3^{\star}[r \geq 1], 55.96^{\star}[r \geq 2], 25.03^{*}[r \geq 3] \\
13.00[r \geq 4] \\
\text { (2) } 112.0^{\star}[r=0], 53.22^{\star}[r \geq 1], 38.22^{\star}[r \geq 2], 19.83^{\star *}[r \geq 3] \\
9.116[r \geq 4]\end{array}$ & $-2.175668^{\star \star}$ \\
\hline Model III & $\begin{array}{l}\text { (1) } 222.3^{*}[r=0], 149.8^{\star}[r \geq 1], 86.78^{\star}[r \geq 2], 48.08^{*}[r \geq 3] \text {, } \\
24.68^{\star}[r \geq 4], 12.41[r \geq 5] \\
\text { (2) } 235.8^{\star}[r=0], 76.71^{\star}[r \geq 1], 45.48^{\star}[r \geq 2], 29.82^{\star}[r \geq 3], \\
19.73^{\star *}[r \geq 4], 8.417[r \geq 5]\end{array}$ & $-2.792482^{\star}$ \\
\hline
\end{tabular}

NOTES Null hypothesis means lack of co-integration, whilst $r$ designates the figure of co-integrating equations through linear deterministic trend; ${ }^{*}$ and ${ }^{* *}$ shows significance at $1 \%$ and $5 \%$ level respectively.

specifically, by employing the Fisher test (Johansen 1992 and Maddala and $\mathrm{Wu}$ 1999) it is evident that there are four co-integrating vector for Model I, and II and five co-integrating vector for Model III at the 5\% level of significance. Kao test (Engle-Granger based) also confirms that there is co-integration among the variables.

\section{ESTIMATION OF LONG-RUN AND SHORT-RUN RELATIONSHIPS USING PMG/ARDL MODEL}

As co-integrating relationship is established among the variables the $\mathrm{PMG} / \mathrm{ARDL}$ technique is applied to estimate both the long and short-run association among $\mathrm{CO}_{2}$ emission, growth, energy intensity, urbanization, population and trade openness using three models. Table 5 depicts the panel PMG/ARDL estimation results.

The outcomes posit statistically significant negative sign of the coefficient of the ЕСM in support of all the countries in all the three models. It indicates any short-term fluctuations stuck between $\mathrm{CO}_{2}$ emission, growth, energy intensity, urbanization, population and trade openness will be corrected to signify a firm long-run correlation involving all the indicators.

Results of the PMG estimation in Model I, demonstrates in the longrun growth, energy intensity, urbanization, population have a positive 
TABLE 5 Panel PMG/ARdL Estimation Results

\begin{tabular}{|c|c|c|c|c|c|c|}
\hline & \multicolumn{2}{|c|}{ Model I } & \multicolumn{2}{|c|}{ Model II } & \multicolumn{2}{|c|}{ Model III } \\
\hline & Variables & Coefficient & Variables & Coefficient & Variables & Coefficient \\
\hline \multirow[t]{6}{*}{ Long-Run } & $\operatorname{LnY}$ & $1.135816^{*}$ & $\mathrm{LnCO}_{2}$ & $-2.156686^{\star}$ & $\operatorname{LnY}$ & $1.482575^{*}$ \\
\hline & LnEI & $1.123813^{*}$ & LnEC & $3 \cdot 345926^{*}$ & $\operatorname{LnY}^{2}$ & $-0.020260^{*}$ \\
\hline & $\operatorname{LnU}$ & $0.299722^{*}$ & $\operatorname{Ln} P$ & $4.327030^{*}$ & LnEI & $1.193408^{*}$ \\
\hline & $\operatorname{LnP}$ & $1.948703^{*}$ & $\operatorname{LnU}$ & $0.465658^{* *}$ & $\operatorname{LnU}$ & $0.323276^{*}$ \\
\hline & LnTO & $-0.15961^{*}$ & LnTO & $0.465637^{*}$ & $\operatorname{LnP}$ & $1.919864^{*}$ \\
\hline & & & & & LnTO & $-0.161750^{*}$ \\
\hline \multirow[t]{20}{*}{ Short-Run } & COINTEQo1 & $-1.10835^{\star}$ & COINTEQo1 & $-0.139377^{* *}$ & ${ }^{*}$ COINTEQo1 & $-1.84179^{\star x}$ \\
\hline & $\mathrm{D}\left(\operatorname{LnCO}_{2}(-1)\right)$ & $0.364831^{* *}$ & * $\mathrm{D}(\operatorname{LnY}(-1))$ & $0.273771 \rrbracket$ & $\left(\mathrm{LnCO}_{2}(-1)\right)$ & 0.715383 \\
\hline & $\mathrm{D}(\mathrm{Ln} \mathrm{Y})$ & 0.084848 & $\mathrm{D}\left(\mathrm{LnCO}_{2}\right)$ & $0.161153 \mathrm{D}$ & $\left(\operatorname{LnCO}_{2}(-2)\right)$ & 0.234347 \\
\hline & $\mathrm{D}(\operatorname{LnY}(-1))$ & $0.276042 \mathrm{D}$ & $\left(\operatorname{LnCO}_{2}(-1)\right)$ & 0.249299 & $\mathrm{D}(\operatorname{LnY})$ & -3.518502 \\
\hline & $\mathrm{D}(\operatorname{LnY}(-2))$ & $0.140655 \mathrm{D}$ & $\left(\operatorname{LnCO}_{2}(-2)\right)$ & $0.212817^{* *}$ & * $\mathrm{D}(\operatorname{LnY}(-1))$ & -10.55889 \\
\hline & $\mathrm{D}(\mathrm{LnEI})$ & $-0.298985 \mathrm{D}$ & $\left(\mathrm{LnCO}_{2}(-3)\right)$ & 0.147800 & $\mathrm{D}(\operatorname{LnY}(-2))$ & 0.393871 \\
\hline & $\mathrm{D}(\operatorname{LnEI}(-1))$ & -0.204336 & $\mathrm{D}(\operatorname{LnEC})$ & -0.207595 & $\mathrm{D}\left(\operatorname{LnY}^{2}\right)$ & -0.066490 \\
\hline & $\mathrm{D}(\operatorname{LnEI}(-2))$ & $0.178209 \mathrm{I}$ & $\mathrm{D}(\operatorname{LnEC}(-1))$ & -0.120845 & $\mathrm{D}\left(\operatorname{LnY}^{2}(-1)\right)$ & 0.880279 \\
\hline & $\mathrm{D}(\mathrm{LnU})$ & $-0.323222^{*} \mathrm{I}$ & $\mathrm{D}(\operatorname{LnEC}(-2))$ & -0.270433 & $\mathrm{D}\left(\operatorname{LnY}^{2}(-2)\right)$ & 0.008849 \\
\hline & $\mathrm{D}(\operatorname{LnU}(-1))$ & $-0.177797^{*} \mathrm{I}$ & $\mathrm{D}(\operatorname{LnEC}(-3))$ & $-0.28617^{* *}$ & $\mathrm{D}(\mathrm{LnEI})$ & -0.976297 \\
\hline & $\mathrm{D}(\operatorname{LnU}(-2))$ & -0.032991 & $\mathrm{D}(\operatorname{Ln} \mathrm{P})$ & -68.15284 & $\mathrm{D}(\operatorname{LnEI}(-1))$ & -0.477997 \\
\hline & $\mathrm{D}(\operatorname{Ln} \mathrm{P})$ & -22.95059 & $\mathrm{D}(\operatorname{LnP}(-1))$ & 355.1662 & $\mathrm{D}(\operatorname{LnEI}(-2))$ & 0.120562 \\
\hline & $\mathrm{D}(\operatorname{Ln} \mathrm{P}(-1))$ & 93.04180 & $\mathrm{D}(\operatorname{Ln} \mathrm{P}(-2))$ & -491.9675 & $\mathrm{D}(\mathrm{Ln} U)$ & $-0.65877^{* *}$ \\
\hline & $\mathrm{D}(\operatorname{LnP}(-2))$ & -42.55090 & $\mathrm{D}(\operatorname{Ln} \mathrm{P}(-3))$ & 211.4901 & $\mathrm{D}(\operatorname{LnU}(-1))$ & $-0.4288^{* x}$ \\
\hline & $\mathrm{D}(\mathrm{LnTO})$ & $0.091509^{\star *}$ & $\mathrm{D}(\mathrm{Ln} U)$ & -0.124524 & $\mathrm{D}(\operatorname{LnU}(-2))$ & $-0.27819^{* *}$ \\
\hline & $\mathrm{D}(\operatorname{LnTO}(-1))$ & $0.113437^{* *}$ & * $\mathrm{D}(\operatorname{Ln} \mathrm{U}(-1))$ & -0.086954 & $\mathrm{D}(\operatorname{LnP})$ & 88.36102 \\
\hline & $\mathrm{D}(\operatorname{LnTO}(-2))$ & -0.029863 & $\mathrm{D}(\operatorname{LnU}(-2))$ & -0.040257 & $\mathrm{D}(\operatorname{Ln} \mathrm{P}(-1))$ & -52.88338 \\
\hline & & & $\mathrm{D}(\mathrm{LnTO})$ & -0.100464 & $\mathrm{D}(\mathrm{LnTO})$ & 0.216703 \\
\hline & & & $\mathrm{D}(\operatorname{LnTO}(-1))$ & -0.085757 & $\mathrm{D}(\operatorname{LnTO}(-1))$ & $0.162117^{* x}$ \\
\hline & & & $\mathrm{D}(\operatorname{LnTO}(-2))$ & $-0.101428^{*} \mathrm{I}$ & $\mathrm{D}(\operatorname{LnTO}(-2))$ & -0.002942 \\
\hline
\end{tabular}

NOTES ${ }^{*},{ }^{* *}$, and ${ }^{* * *}$ shows statistical significance at the $1 \%, 5 \%$ and $10 \%$ level correspondingly.

significant impact but trade openness has negative significant impact on $\mathrm{CO}_{2}$ emissions. In short-run urbanization seems to have negative impact and trade openness has positive impact on $\mathrm{CO}_{2}$ emissions. In Model II, energy consumption, urbanization, trade openness and population has statistically significant positive effect but the effect of $\mathrm{CO}_{2}$ emissions is negative on growth also found by Martínez-Zarzoso and BengocheaMorancho (2004) and (Liu 2005). Energy consumption, urbanization and trade openness have positive but insignificant association with per capita GDP in the short-run. Model III, estimates all the variables have positive 
noteworthy effect on $\mathrm{CO}_{2}$ emissions for except the quadratic form of GDP per capita which in the long-run has negative impact. It shows the presence of EKC hypothesis (Kuznets 1955) which implies that there exists an reversed curved association linking $\mathrm{CO}_{2}$ emission and other economic variables used in this study. In short-run urbanization shows significant negative association with $\mathrm{CO}_{2}$ emissions.

\section{Results of Short-run and Long-run Granger Causality Test}

To analyze the short-run and long-run causal relationship, Granger Causality in the VЕсм framework is estimated and table 6 illustrates the outcomes.

The existence of co-integration among the series implies that causality must be present at least in one direction. Granger Causality results in the VECM framework shows: In Model I all the independent variables have unidirectional short-run causal relationship with dependent variable.

Per capita GDP (DLnY) and energy intensity (DLnEI) has bidirectional causal relationship with $\mathrm{CO}_{2}$ emission $\left(\mathrm{DLnCO}_{2}\right)$. Model II specifies unidirectional short-run causality from independent to dependent variables. It is evident from Model III, all the independent variables have unidirectional short-run causal relationship with the predicted variable and per capita GDP (DLnY) and squared per capita GDP (DLnY ${ }^{2}$ ) and energy intensity (DLnEI) has bidirectional causal relationship with dependent variable. On the other hand, a significant t-test on a negative ECT (error correction term) exhibits long-run causality in all the three equations. This result postulates that per capita GDP (i.e. economic growth) encourages energy intensity in four Asian economies. For that reason, energy conservation actions that do not discourage growth should be promoted. The connection involving $\mathrm{CO}_{2}$ emissions and energy intensity shows substantiation of bidirectional causality implying that emissions lead to energy use and vice versa. From the result it is discernible that though apparently it seems to be impossible to trim down $\mathrm{CO}_{2}$ emissions if energy utilization is not reduced but at an advanced plane of growth, per capita GDP is found to be negatively related with $\mathrm{CO}_{2}$ emission. This phenomenon implies after reaching a certain level of growth emission decreases.

FURTHER ANALYSIS FOR ROBUSTNESS CHECK

Previously in the above panel estimations, the results are estimated taking the panel data as a whole. To examine the country specific impacts 


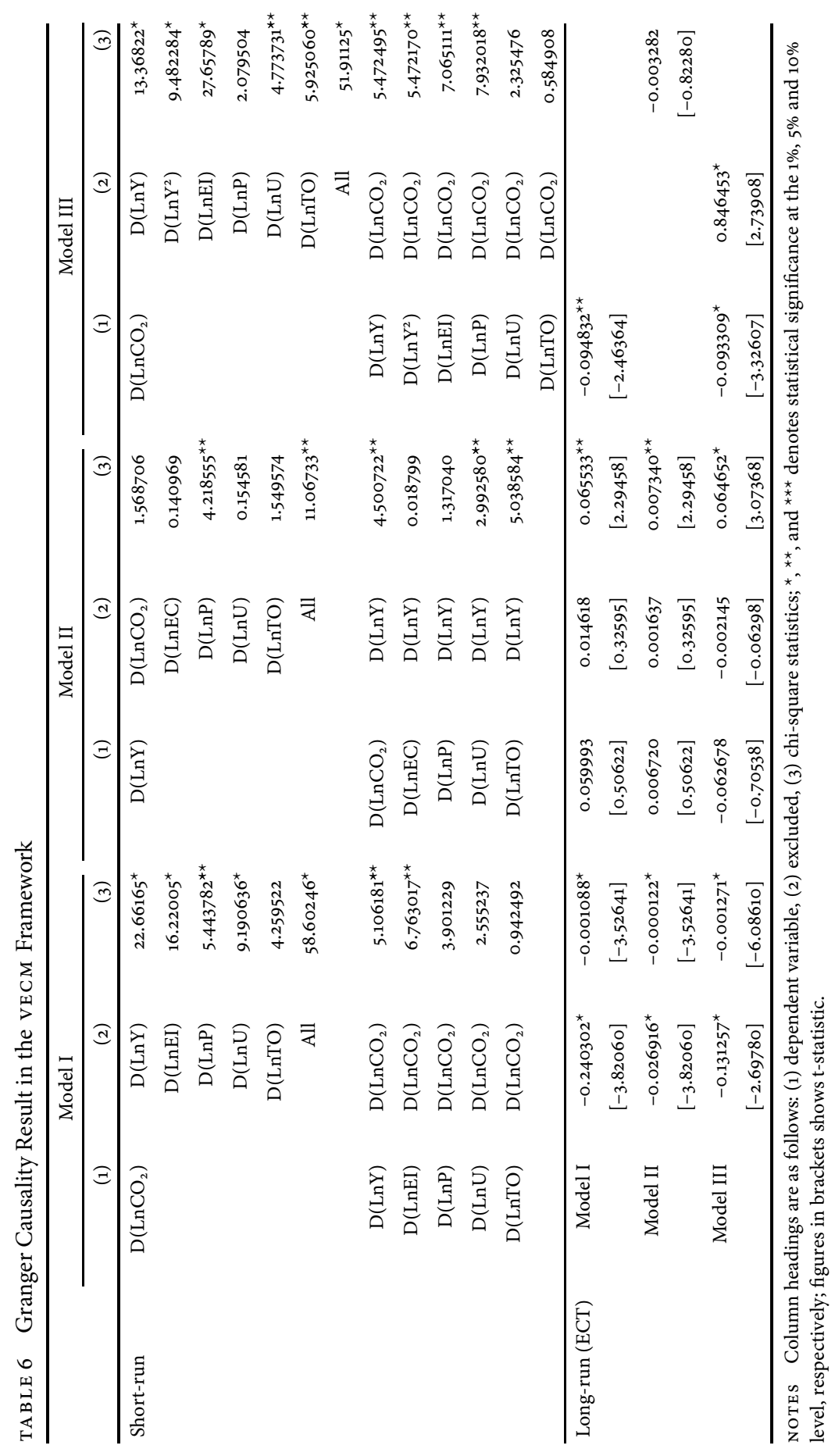


TABLE 7 Cross-Section Short-Run eCt of the Three Models

\begin{tabular}{lllllllll}
\hline Economies & \multicolumn{2}{c}{ Model I } & & \multicolumn{2}{c}{ Model II } & & \multicolumn{2}{c}{ Model III } \\
\cline { 2 - 3 } & Coefficient & Probability & & Coefficient & Probability & & Coefficient & Probability \\
\hline Bangladesh & -1.155122 & 0.0000 & -0.197151 & 0.0000 & & -1.519505 & 0.0001 \\
India & -0.358313 & 0.0001 & -0.260365 & 0.0000 & -0.528018 & 0.0000 \\
China & -1.625032 & 0.0000 & -0.152188 & 0.0000 & -3.967601 & 0.0002 \\
Indonesia & -1.294944 & 0.0004 & 0.052194 & 0.0001 & -1.352071 & 0.0012 \\
\hline
\end{tabular}

cross-section short-run Е С $\mathrm{T}$ of the three models provided in table 7 are observed.

The results divulge that the calculated ЕСT for all the four economies has statistically significant negative sign for all the three models except for Indonesia in Model II. However, the speeds of adjustments diverge significantly.

As far as cross-section short-run coefficients of the three models are concerned, model I exhibit, in the short-run urbanization shows significant negative effect for all economies except for Indonesia whereas trade openness has positive significant effect on $\mathrm{CO}_{2}$ emission for all economies. Regarding energy intensity all countries poses negative association except for India which shows positive impact on $\mathrm{CO}_{2}$ emission. In Model II, the short-run result specifies, $\mathrm{CO}_{2}$ emission and energy consumption is positively related to GDP per capita except for Indonesia and trade openness is negatively related for all the stipulated economies. Furthermore, in Model III, energy intensity shows negative impact except for India and urbanization and trade openness shows negative and positive impact on $\mathrm{CO}_{2}$ emission respectively in the short run for all economies.

\section{Conclusion and Policy Implications}

The study empirically looks into the interactions among economic growth, population growth energy consumption, urbanization, energy intensity and $\mathrm{CO}_{2}$ emission addressing the sustainable development stance. Findings postulate that economic growth is determined by energy consumption, as a consequence of this $\mathrm{CO}_{2}$ emission springs forth. The projected findings show that $\mathrm{CO}_{2}$ emission is affected by the consumption of energy, economic growth and urbanization within 35 years. Therefore, it is visible that energy use directs GDP growth. The findings from the direction of the causality test also indicate the need for suitable policies to meet increasing energy demand caused by economic growth to sup- 
port continuous economic growth. The findings will provide valuable policy implications for the four developing Asian countries as well as to other developing countries. Crucial apprehension is that $\mathrm{CO}_{2}$ emissions cause environmental degradation for instance, global warming and climate change. In the process of economic growth and development, energy consumption, population, urbanization, $\mathrm{CO}_{2}$ emissions are acting as stimulators. Despite the strong association among the variables there are approaches to avert environmental impact on growth in a sustainable manner. Thus to ease the specter it is imperative to consider the potential harmful impacts they have on the growth process and in initiating the energy preservation strategies.

Economic development, urbanization and population growth is the reason behind energy requirement amplification resulting in $\mathrm{CO}_{2}$ emission and global warming in the four economies of the study. Hence, Energy consumption, energy intensity, urbanization, population, and trade openness strategies should deem economies' revenue intensity at every phase of advancement. Moreover, long-run as well as short-run consequences need to be considered to ease $\mathrm{CO}_{2}$ emissions related predicament in environmental management and sustainable development perception. The research focus is on the economic, social and environmental aspect of sustainable development goals and further research should take into consideration the political and governance related institutional issues.

\section{References}

Agras, J., and D. Chapman. 1999. 'A Dynamic Approach to the Environmental Kuznets Curve Hypothesis.' Ecological Economics 28 (2): 26777.

Al-Mulali, U., B. Saboori, and I. Ozturk. 2015. 'Investigating the Environmental Kuznets Curve Hypothesis in Vietnam.' Energy Policy 76:123-31.

Andreoni, J., and A. Levinson. 2001. 'The Simple Analytics of the Environmental Kuznets Curve.' Journal of Public Economics 8o (2): 269-86.

Chen, H., B. Jia, and S. S. Y. Lau. 2008. 'Sustainable Urban Form for Chinese Compact Cities: Challenges of a Rapid Urbanized Economy.' Habitat International 32 (1): 28-40.

Choi, I. 2001. 'Unit Root Tests for Panel Data.' Journal of International Money and Finance 20 (2): 249-72.

Christopoulos, D. K., and E. G. Tsionas. 2003. 'A Reassessment of Balance of Payments Constrained Growth: Results from Panel Unit Root and Panel Cointegration Tests.' International Economic Journal 17 (3): 3954 . 
Cole, M. A., and E. Neumayer. 2004. 'Examining the Impact of Demographic Factors on Air Pollution.' Population and Environment 26 (1): 5-21.

Dietz, T., and E. A. Rosa. 1997. 'Effects of Population and Affluence on $\mathrm{CO}_{2}$ Emissions.' Proceedings of the National Academy of Sciences 94 (1): 17579.

Ehrlich, P. R., and J. P. Holdren. 1971. 'Impact of Population Growth'. Science 171 (3977): 1212-7.

Friedl, B., and M. Getzner. 2003. 'Determinants of $\mathrm{CO}_{2}$ Emissions in a Small Open Economy'. Ecological Economics 45 (1): 133-48.

Galeotti, M., and A. Lanza. 1999. 'Richer and Cleaner? A Study on Carbon Dioxide Emissions in Developing Countries.' Energy Policy 27 (10): 565-73.

Grossman, G. M., and A. B. Krueger. 1991. 'Environmental Impacts of a North American Free Trade Agreement.' N B E R Working Papers 3914, National Bureau of Economic Research, Cambridge, MA.

Halicioglu, F. 2009. 'An Econometric Study of $\mathrm{CO}_{2}$ Emissions, Energy Consumption, Income and Foreign Trade in Turkey'. Energy Policy 37 (3): 1156-64.

Hamit-Haggar, M. 2012. 'Greenhouse Gas Emissions, Energy Consumption and Economic Growth: A Panel Cointegration Analysis from Canadian Industrial Sector Perspective.' Energy Economics 34 (1): 35864.

Holtz-Eakin, D. and T. M. Selden. 1995. 'Stoking the Fires? $\mathrm{CO}_{2}$ Emissions and Economic Growth' Journal of Public Economics 57 (1): 85-101.

Hossain, S. 2011. 'Panel Estimation for $\mathrm{CO}_{2}$ Emissions, Energy Consumption, Economic Growth, Trade Openness and Urbanization of Newly Industrialized Countries.' Energy Policy 39 (11): 6991-9.

Im, K. S., M. H. Pesaran, and Y. Shin. 2003. 'Testing for Unit Roots in Heterogeneous Panels.' Journal of Econometrics 115 (1): 53-74.

Jalil, A., and S. F. Mahmud. 2009. 'Environment Kuznets Curve for $\mathrm{CO}_{2}$ Emissions: A Cointegration Analysis for China.' Energy Policy 37 (12): 5167-72.

Jayanthakumaran, K., R. Verma, and Y. Liu. 2012. ' $\mathrm{CO}_{2}$ Emissions, Energy Consumption, Trade and Income: A Comparative Analysis of China and India.' Energy Policy 42:450-60.

Johansen, S. 1992. 'Cointegration in Partial Systems and the Efficiency of Single-Equation Analysis.' Journal of Econometrics 52 (3): 389-402.

Kao, C. 1999. 'Spurious Regression and Residual-Based Tests for Cointegration in Panel Data.' Journal of Econometrics 90 (1): 1-44.

Kasman, A., and Y. Selman Duman. 2015. ' $\mathrm{CO}_{2}$ Emissions, Economic Growth, Energy Consumption, Trade and Urbanization in New EU 
Member and Candidate Countries: A Panel Data Analysis.' Economic Modelling 44:97-103.

Kuznets, S. 1955. 'Economic Growth and Income Inequality'. The American Economic Review 45 (1): 1-28.

Levin, A., C.-F. Lin, and C.-S. J. Chu. 2002. 'Unit Root Tests in Panel Data: Asymptotic and Finite-Sample Properties.' Journal of Econometrics 108 (1): $1-24$.

Liddle, B. 2004. 'Demographic Dynamics and per Capita Environmental Impact: Using Panel Regressions and Household Decompositions to Examine Population and Transport.' Population and Environment 26 (1): $23-39$.

Liu, X. 2005. 'Explaining the Relationship between $\mathrm{CO}_{2}$ Emissions and National Income - The Role of Energy Consumption.' Economics Letters $87(3): 325-8$.

Maddala, G. S., and S. Wu. 1999. 'A Comparative Study of Unit Root Tests with Panel Data and a New Simple Test.' Oxford Bulletin of Economics and Statistics 61 (s1): 631-52.

Martínez-Zarzoso, I., and A. Bengochea-Morancho. 2004. 'Testing for Environmental Kuznets Curves for $\mathrm{CO}_{2}$ : Evidence from Pooled Mean Group Estimates.' Economic Letters 82 (1): 121-6.

McConnell, K. E. 1997. 'Income and the Demand for Environmental Quality. Environment and Development Economics 2 (4): 383-99.

McGee, J. A., and R. York. 2018. 'Asymmetric Relationship of Urbanization and $\mathrm{CO}_{2}$ Emissions in Less Developed Countries.' PloS One 13 (12): e0208388. https://doi.org/10.1371/journal.pone.0208388.

Panayotou, T. 1993. Empirical Tests and Policy Analysis of Environmental Degradation at Different Stages of Economic Development. Geneva: International Labour Office.

Pao, H.-T., and C.-M. Tsai. 2010. ' $\mathrm{CO}_{2}$ Emissions, Energy Consumption and Economic Growth in B RIC Countries.' Energy Policy 38 (12): $7850-$ 60.

Pesaran, M. H. 2007. 'A Simple Panel Unit Root Test in the Presence of Cross-Section Dependence.' Journal of Applied Econometrics 22 (2): 265-312.

Pesaran, M. H., Y. Shin, and R. P. Smith. 1999. 'Pooled Mean Group Estimation of Dynamic Heterogeneous Panels.' Journal of the American Statistical Association 94 (446): 621-34.

- 2001. 'Bounds Testing Approaches to the Analysis of Level Relationships.' Journal of Applied Econometrics 16 (3): 289-326.

Rafiq, S., R. Salim, and I. Nielsen. 2016. 'Urbanization, Openness, Emissions, and Energy Intensity: A Study of Increasingly Urbanized Emerging Economies.' Energy Economics 56:20-8. 
Rhodes, C. J. 2016. 'The 2015 Paris Climate Change Conference: cop 21.' Science Progress 99 (1): 97-104.

Sachs, J., T. Panayotou, and A. Peterson. 1999. 'Developing Countries and the Control of Climate Change: Empirical Evidence.' CAE R II Discussion Paper 45, Harvard Institute for International Development, Cambridge, MA.

Sadorsky, P. 2014. 'The Effect of Urbanization on $\mathrm{CO}_{2}$ Emissions in Emerging Economies.' Energy Economics 41:147-53.

Selden, T. M., and D. Song. 1994. 'Environmental Quality and Development: Is There a Kuznets Curve for Air Pollution Emissions?' Journal of Environmental Economics and Management 27 (2): 147-62.

Shafik, N., and S. Bandyopadhyay. 1992. Economic Growth and Environmental Quality: Time-Series and Cross-Country Evidence. Washington, DC: World Bank.

Sharma, S. S. 2011. 'Determinants of Carbon Dioxide Emissions: Empirical Evidence from 69 Countries.' Applied Energy 88 (1): 376-82.

Sharmin, M. 2021. 'Relationship of Renewable and Non-Renewable Energy Utilization with $\mathrm{CO}_{2}$ Emission of Bangladesh.' Energy Economics Letters 8 (1): 49-59.

Sharmin, M., and M. Tareque. 2018. 'Econometric Analysis of the Effect of Economic Globalization, Energy Intensity, Urbanization, Industrialization and Growth on $\mathrm{CO}_{2}$ Emissions of Bangladesh.' Managing Global Transitions: International Research Journal 16 (4): 335-54.

York, R. 2007. 'Demographic Trends and Energy Consumption in European Union Nations, 1960-2025.' Social Science Research 36 (3): 855-72.

York, R., E. A. Rosa, and T. Dietz. 2003. 'Footprints on the Earth: The Environmental Consequences of Modernity'. American Sociological Review 68 (2): 279-300.

Zhang, X.-P., and X.-M. Cheng. 2009. 'Energy Consumption, Carbon Emissions, and Economic Growth in China.' Ecological Economics 68 (10): 2706-12. 
Vpliv prevzema tehnologije na inovacije novih izdelkov T. Joseph Musandiwa in Collins C. Ngwakwe

Ta članek preučuje učinek licenciranja tuje tehnologije na inovacije novih izdelkov in dostop do trga. Podatki glede petdesetih držav so bili zbrani iz arhivov Ankete o globalnih podjetjih Svetovne banke. Podatki so bili analizirani z uporabo modela strukturnih enačb (SEM), s pomočjo programske opreme stata. Rezultati sem kažejo, da je licenciranje zunanje tehnologije pozitivno in znatno povezano $\mathrm{z}$ novostmi novih izdelkov ter dostopom do trga. Vendar pa moderiranje neodvisne spremenljivke (uporaba spletnega mesta) ni pokazalo znatne povezave z novimi izdelki in dostopom do trga. Prispevek prikazuje praktične posledice za inovacije novih izdelkov, to je, da lahko lokalna podjetja notranje stroške in čas za raziskave ter razvoj novih izdelkov prihranijo s sprejetjem možnosti licenciranja tuje tehnologije. Prednost licenciranja tuje tehnologije pa je tudi v tem, da le-to lokalnim podjetjem pomaga, da na trgu ponudijo nov izdelek. Priporočamo nadaljnje raziskave, ki bi dodale več držav, s katerimi bi povečali število opazovanj.

Ključne besede: prevzem tehnologije, inovacije izdelkov, tuja tehnologija, licenciranje tehnologije

Klasifikacija JEL: 032, O3, O31, 033, L6, M1

Managing Global Transitions 18 (3): 177-194

\section{Razmerje med impulzivnostjo, vrednostnimi usmeritvami in impulzivnim nakupom \\ Katarina Sokić, Darija Korkut in Aljoša Šestanović}

Cilj te študije je bil preučiti vlogo impulzivnosti in vrednostnih usmeritev pri impulzivnem nakupu na primernem vzorcu iz Zagreba $(N=\mathbf{2 2 0}$, $44 \%$ moških, starosti od 20 do 55 let; $\left.\mathrm{M}_{\text {age }}=26,07, \mathrm{sD}=7,14\right)$. Pri tem smo uporabili Barrattovo lestvico impulzivnosti, lestvico nakupne impulzivnosti in lestvico orientacijske vrednosti. Rezultat je pokazal, da je impulziven nakup povezan s pozornostjo, motorično in nenačrtovano impulzivnostjo. Rezultati so pokazali tudi pozitivno povezavo med impulzivnimi nakupnimi težnjami in hedonistično vrednostno usmerjenostjo. Hierarhična regresijska analiza je pokazala, da motorična in nenačrtovana impulzivnost, ne pa tudi impulzivnost pozornosti, pozitivno napovedujeta impulzivne nakupne tendence. Poleg tega so impulzivnost 
in vrednostne usmeritve pojasnile 35-odstotne razlike v tendencah impulzivnih nakupov. Rezultati kažejo, da je impulzivno nakupno vedenje povezano predvsem s hedonistično vrednostno usmerjenostjo.

Ključne besede: impulzivnost, vrednostne usmeritve, impulziven nakup Klasifikacija JEL: A13, D12, D87, D91

Managing Global Transitions 18 (3): 195-210

\section{Analiza sodelovanja med podjetji in javnimi raziskovalnimi organizacijami pri sofinanciranih raziskovalno-razvojnih projektih}

Tina Žitko in Borut Likar

Sodelovanje med podjetji in javnimi raziskovalnimi organizacijami ( $\mathrm{RO}$ ) je pomemben dejavnik gospodarske uspešnosti in razvoja države. Navedeno se nanaša na cilj pričujoče študije, v kateri smo prepoznali učinke, rezultate, razloge za (ne)sodelovanje in prednosti/slabosti sodelovanja med podjetji in J RO-ji z vidika podjetij in podjetniških grozdov. Naši rezultati kažejo, da se razlog za sodelovanje med podjetji in JRO-ji nahaja bolj v doseganju prebojnih rezultatov kot pa v finančni koristi. Med ovire, ki ovirajo takšno sodelovanje med univerzami in industrijo, so birokracija, neustrezno osebje, nizke finančne spodbude, nepoznavanje razpisov za projekte in pomanjkanje pobude v imenu JRO-jev pri vzpostavljanju stikov. Med najpomembnejšimi učinki takšnega sodelovanja so vstop na nove trge, napredek na področju človeških virov in vzpostavljanje novih partnerstev. Manj pomembni učinki vključujejo ustanavljanje podjetij start-up in dobičke, pridobljene s strani patentov in licenc. Čeprav se razvoj novih izdelkov/storitev in njihova ponudba na trgu štejeta za pomembna, se znanstveni dosežki in podeljeni patenti štejejo med manj pomembne rezultate. Tako bi bilo treba sodelovanje med univerzami in industrijo izboljšati s pogostejšim sodelovanjem, z izmenjavo znanja, osebami za vzdrževanje zvez, s poenostavljenim upravljanjem, $\mathrm{z}$ ustreznim upravljanjem pravic intelektualne lastnine in večjo javno prepoznavnostjo.

Ključne besede: podjetja, JRO-ji, sodelovanje, prenos znanja, podjetniški grozdi

Klasifikacija JEL: 032

Managing Global Transitions 18 (3): 211-236 
Povezava trajnostne rasti in okolja v kontekstu štirih azijskih držav v razvoju: panelna analiza

\section{Mowshumi Sharmin in Mohammad Tareque}

Ta članek je uporabil model STIRPAT za raziskovanje sinergijskega učinka emisij $\mathrm{CO}_{2}$, porabe energije, energetske intenzivnosti, gospodarske rasti, prebivalstva, urbanizacije in odprtosti trgovine za prikaz povezave med rastjo in okoljem $\mathrm{v}$ štirih izbranih azijskih državah v razvoju. Pričujoča študija je vzela za primer pregled sklopa podatkov iz Bangladeša, Kitajske, Indije in Indonezije ter uporabila model ARDL (avtoregresijski model z eksogenimi regresorji) in Grangerjev test vzorčnosti (angl. vec Granger Causality/Block Exogeneity Wald Tests). Empirični rezultati kažejo, da so razlogi za emisije $\mathrm{CO}_{2}$ energetska intenzivnost, urbanizacija, prebivalstvo in rast в D Р na prebivalca, medtem ko je ugotovljeno, da je odprtost za trgovanje $\mathrm{z}$ emisijami $\mathrm{CO}_{2}$ negativno povezana. Nasprotno pa so poraba energije, urbanizacija, prebivalstvo in odprtost za trgovanje pozitivno povezani z в D P na prebivalca. Poleg tega preučujemo tudi hipotezo o okoljski Kuznetsovi krivulji (E KC), ugotovitve pa utemeljujejo obrnjeno razmerje v obliki črke U. Za preverjanje trdnosti rezultatov tega pregleda preučimo kratkoročne koeficiente preseka podatkov na ravni države.

Ključne besede: hipoteza oкк (E KC), model st IR PAт, emisija $\mathrm{CO}_{2}$, urbanizacija, poraba energije

Klasifikacija JEL: C33, O44, Q43

Managing Global Transitions 18 (3): 237-256 